\title{
One-Carbon Metabolism: Pulling the Strings behind Aging and Neurodegeneration
}

\author{
Eirini Lionaki ${ }^{1,+(D)}$, Christina Ploumi ${ }^{1,2,+(D)}$ and Nektarios Tavernarakis $1,2, *(D)$ \\ 1 Institute of Molecular Biology and Biotechnology, Foundation for Research and Technology-Hellas, \\ 70013 Heraklion, Crete, Greece; lionaki@imbb.forth.gr (E.L.); ploumi@imbb.forth.gr (C.P.) \\ 2 Department of Basic Sciences, Faculty of Medicine, University of Crete, 70013 Heraklion, Crete, Greece \\ * Correspondence: tavernarakis@imbb.forth.gr; Tel.: +30-2810-391069 \\ + These authors contributed equally to this work.
}

Citation: Lionaki, E.; Ploumi, C.; Tavernarakis, N. One-Carbon Metabolism: Pulling the Strings behind Aging and

Neurodegeneration. Cells 2022, 11, 214. https://doi.org/10.3390/ cells11020214

Academic Editors: Natascia Ventura and Judith Haendeler

Received: 12 December 2021

Accepted: 6 January 2022

Published: 9 January 2022

Publisher's Note: MDPI stays neutral with regard to jurisdictional claims in published maps and institutional affiliations.

Copyright: (C) 2022 by the authors. Licensee MDPI, Basel, Switzerland. This article is an open access article distributed under the terms and conditions of the Creative Commons Attribution (CC BY) license (https:// creativecommons.org/licenses/by/ $4.0 /)$.

\begin{abstract}
One-carbon metabolism (OCM) is a network of biochemical reactions delivering onecarbon units to various biosynthetic pathways. The folate cycle and methionine cycle are the two key modules of this network that regulate purine and thymidine synthesis, amino acid homeostasis, and epigenetic mechanisms. Intersection with the transsulfuration pathway supports glutathione production and regulation of the cellular redox state. Dietary intake of micronutrients, such as folates and amino acids, directly contributes to OCM, thereby adapting the cellular metabolic state to environmental inputs. The contribution of OCM to cellular proliferation during development and in adult proliferative tissues is well established. Nevertheless, accumulating evidence reveals the pivotal role of OCM in cellular homeostasis of non-proliferative tissues and in coordination of signaling cascades that regulate energy homeostasis and longevity. In this review, we summarize the current knowledge on OCM and related pathways and discuss how this metabolic network may impact longevity and neurodegeneration across species.
\end{abstract}

Keywords: aging; Alzheimer's disease; diet; folate; metabolism; methionine; mitochondria; neurodegeneration; one-carbon vitamins; Parkinson disease

\section{Introduction}

One-carbon metabolism (OCM) refers to the complex network of biochemical reactions that mediate delivery of one-carbon units to various anabolic pathways [1]. The term "folate" describes a family of methyl donors that act mainly as enzymatic co-factors in vital interlinked anabolic pathways mainly required for DNA synthesis and amino-acid homeostasis. Folates share a common structure comprised of three chemically distinct moieties: the pteridine ring, the para-aminobenzoic acid (PABA) linker, and a tail of glutamic acid or polyglutamate. The pteridine ring and PABA are linked through a methylene bridge, which facilitates the binding of $1 \mathrm{C}$ units (attachment in the N-5 atom of the pteridine ring and the $\mathrm{N}-10$ atom of the PABA linker). In contrast to plants, fungi, and certain prokaryotic organisms, which can synthesize de novo folate, mammals depend on its dietary uptake [2-5]. Uptake of folates across epithelia and into mammalian cells is facilitated by three transport systems, the Reduced Folate Carrier (RFC), the Proton-Coupled Folate Transporter (PCFT), and the Folate Receptors (FRs) [6,7]. PCFT is expressed mainly in the upper gastrointestinal tract and in tumors, supporting transport of folates under acidic conditions [8,9]. RFC is an organic anion antiporter expressed ubiquitously and is the major tissue folate transporter $[10,11]$. Folate receptors can be either the high affinity glycosylphosphatidylinositol (GPI)-anchored receptors (FR $\alpha$ and FR $\beta$ ) that mediate folate transport via endocytosis or the soluble and secreted low affinity receptors (FR $\gamma$ and FR $\delta$ ) [12-15].

All natural folates differ in the oxidation state of the pteridine ring and are present in their reduced form, compared to the fully oxidized and monoglutamated folic acid, which is commonly used as a synthetic food supplement. Dietary absorption of folates occurs in 
the small intestine, where they are initially subjected to hydrolysis of their poly-glutamated tail to a mono-glutamated form. Once directed to the target cells, folate mono-glutamates are transformed to 5-methyl-tetrahydrofolate (5-methyl-THF), which is the predominant form of folates in animal tissues, and subsequently they are poly-glutamated again to participate in one-carbon reactions.

\section{One-Carbon Metabolic Pathways}

OCM is highly compartmentalized, since parallel, interconnected pathways exist in the cytosol, mitochondria, and nucleus [16]. In the following section we are analyzing in detail the OCM pathways in the distinct cellular compartments (summarized in Figure 1).

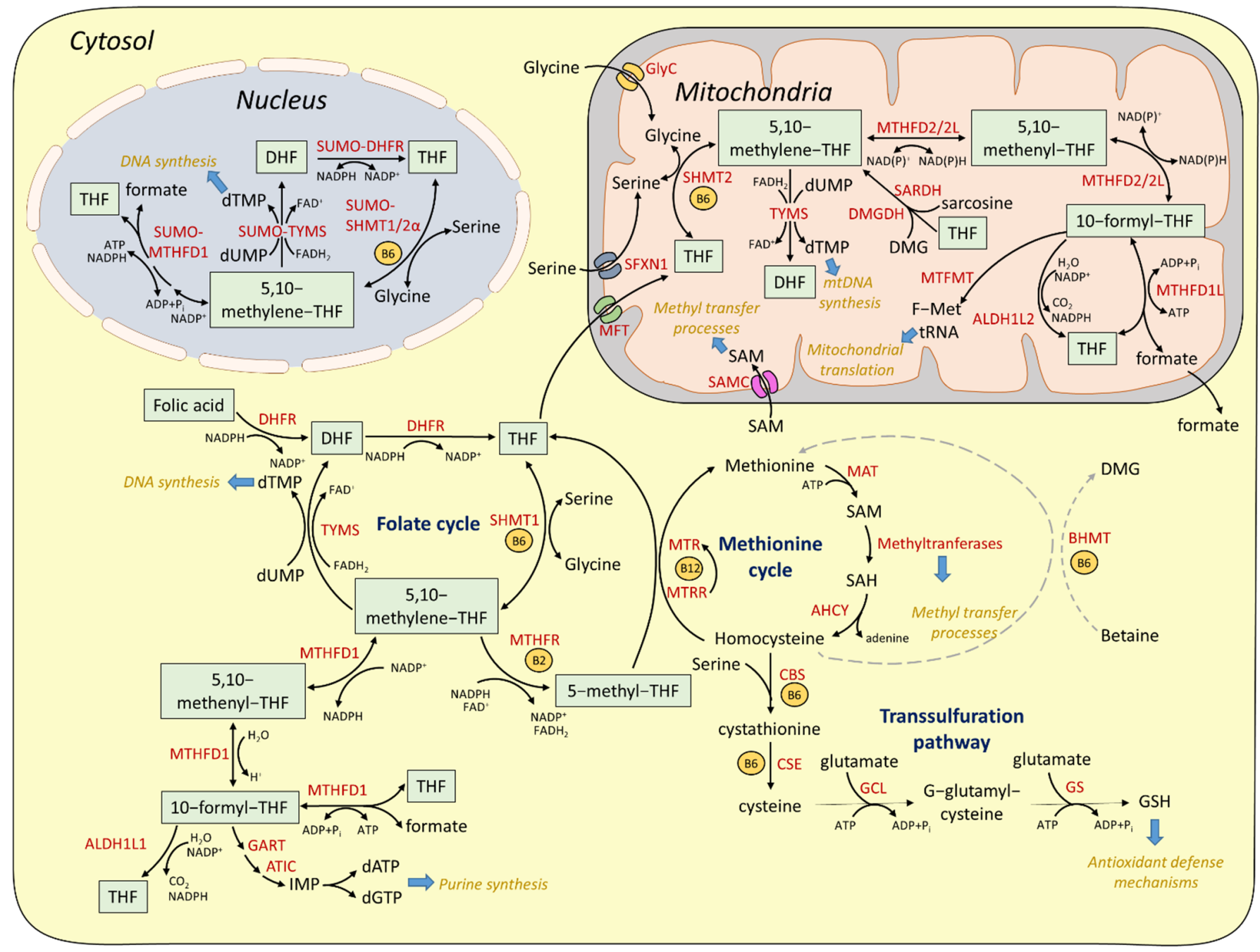

Figure 1. One-carbon metabolic pathways. Intersections of OCM pathways in cytosolic, nuclear, and mitochondrial compartments, based on mammalian systems. The involved folate forms are depicted in green boxes, while the respective enzymes are written in red.

\subsection{Cytosolic and Nuclear Pathways of One-Carbon Metabolism}

Folic acid, the synthetic, fully oxidized, and monoglutamated form of folate, is first reduced to dihydrofolate (DHF) and then to tetrahydrofolate (THF) by DHF reductase (DHFR), which uses nicotinamide adenine dinucleotide phosphate (NADPH) as an electron donor. Cytosolic THF is then converted to 5,10-methylene-THF by the vitamin B6dependent enzyme serine hydroxymethyltransferase 1 (SHMT1). This reaction is reversible and simultaneously converts serine to glycine [1]. 
Thymidylate synthase (TYMS) uses 5,10-methylene-THF to catalyze the methylation of deoxyuridylate (dUMP) to deoxythymidylate (dTMP) upon oxidation of a dihydroflavineadenine dinucleotide $\left(\mathrm{FADH}_{2}\right)$ molecule. TYMS-mediated de novo thymidylate generation is indispensable for DNA synthesis and is compartmentalized apart from the cytosol, in mitochondria and nucleus [17,18]. The removal of a $1 \mathrm{C}$ unit from 5,10-methylene-THF for dTMP synthesis converts the latter to DHF, which in turn can be transformed again to THF and 5,10-methylene-THF through the aforementioned reactions.

5,10-methylene-THF can be irreversibly converted to 5-methyl-THF by the vitaminB2-dependent methylene-THF-reductase (MTHFR) in a process accompanied by oxidation of NADPH to $\mathrm{NADP}^{+}$and the concomitant reduction of FAD to $\mathrm{FADH}_{2}$. Methionine synthase (MTR) in conjunction with vitamin B12 demethylates 5-methyl THF (conversion to THF) by donating its $1 \mathrm{C}$ unit to homocysteine (Hcy) and transforming it to methionine. MTR is regenerated to a functional state by Methionine Synthase Reductase (MTRR) after each cycle of methionine synthesis. The conversion of THF to 5,10-methylene-THF and then back to THF completes a series of reactions, known as the folate cycle. Methionine, produced by the remethylation of Hcy, is subsequently adenylated by methionine adenosyltransferase (MAT) to generate S-adenosylmethionine (SAM) by using an ATP molecule as a co-substrate. SAM is the major methyl donor for vital cellular processes and the master regulator of epigenetic mechanisms [19]. Donation of its methyl group converts SAM to S-adenosylhomocysteine (SAH), which in turn is converted to Hcy after removal of the adenosine molecule, through a reversible process mediated by S-adenosylL-homocysteine hydrolase (AHCY) [20]. In mammalian liver and kidney cells, Hcy can be recycled back to methionine through an alternative mechanism mediated by the $\mathrm{Zn}^{2+}$ - and B6-dependent enzyme betaine-homocysteine methyltransferase (BHMT). This reaction uses betaine (trimethylglycine) as a methyl donor, which is acquired either by dietary uptake, or as a byproduct of choline degradation [21].

Sufficient levels of methionine enable the entry of Hcy in the transsulfuration pathway. B6-dependent Cystathionine beta synthase (CBS) catalyzes the first step by condensing Hcy and serine through a beta-replacing reaction, to finally generate cystathionine. Cystathionine is then converted to cysteine by cystathionine $\gamma$-lyase (CSE) [22]. Sequentially, cysteine is finally converted to glutathione through an energy-consuming, two-step enzymatic process. Firstly, glutamate cysteine ligase (GCL) couples glutamate to cysteine-generating G-glutamyl-cysteine. In turn, G-glutamyl-cysteine is conjugated to glycine through GSH synthase (GS), finally forming GSH [22]. The transsulfuration pathway is mainly regulated by SAM, which inhibits the MTHFR-mediated formation of 5-methyl THF, while it enhances CBS activity [23,24].

Apart from its involvement in the methionine/Hcy cycle, 5,10-methylene-THF can be utilized for formate and purine synthesis. In the cytosol, 5,10-methylene-THF, produced by SHMT1, is first converted to 5,10-methenyl-THF through the reduction of NADP+ to $\mathrm{NADPH}$ and then to 10-formyl-THF through hydrolysis. This is a reversible two-step process, catalyzed by methylene-THF dehydrogenase 1 (MTHFD1) through its methylene-THF dehydrogenase and methenyl-THF cyclohydrolase activities, respectively. Once formed, 10-formyl-THF can be reversibly converted to THF and formate, in an ATP-producing process mediated by the formyl C1-tetrahydrofolate synthetase activity of MTHFD1 [25,26]. Alternatively, 10-formyl-THF is utilized for de novo purine (adenine and guanine) synthesis. De novo purine synthesis is an 11-step process, resulting in the generation of inosine monophosphate (IMP) and its subsequent conversion to either guanosine monophosphate (GMP) or adenosine monophosphate (AMP). The main enzymes involved are glycinamide ribonucleotide transformylase (GART) and 5-aminoimidazole-4-carboxamide ribonucleotide formyltransferase/IMP cyclohydrolase (ATIC), and the process occurs in specialized multi-enzyme complexes, known as the purinosomes [27]. Additionally, 10-formyl-THF can be converted to THF in a process generating NADPH and $\mathrm{CO}_{2}$. This reaction requires the enzymatic activity of cytosolic aldehyde dehydrogenase 1 family member L1 (ALDH1L1) [28]. 
In the nucleus, folates are mainly used to support de novo dTMP synthesis for DNA replication. Similar to the cytosolic pathway, the activity of DHFR, TYMS, and SHMT1 is required for the interconversion between THF, 5,10-methylene-THF and DHF in the nucleus. SHMT $2 \alpha$, produced by alternative splicing of the serine hydroxymethyltransferase 2 (SHMT2) gene, functions redundantly to SHMT1 in the nucleus [29]. Interestingly, during the $S$ and $G_{2} / M$ phases, the aforementioned enzymes are translocated to the nucleus, where they form a multi-enzyme complex in conjunction with proteins of the nuclear lamina, as well as with DNA replication and repair factors [30]. Cytosolic formate, mainly derived by the mitochondrial pathway, is also used as a nuclear one-carbon source for the production of 5,10-methylene-THF, requiring the activity of the MTHFD1 enzyme [31]. Post-translational modification with the small ubiquitin-like modifier (SUMO) protein is required for the nuclear translocation of TYMS, DHFR, SHMT1, SHMT2 $\alpha$, and MTHFD1 [30,32,33].

\subsection{Mitochondrial One-Carbon Metabolism}

Given the lack of DHFR activity in mitochondria, the mitochondrial folate cycle depends on the import of reduced monoglutamate folate forms, which could be either monoglutamate THF or 5-formyl-THF [34]. The import of monoglutamated folates across the inner mitochondrial membrane (IMM) is mediated by the specialized transporter MFT (mitochondrial folate transporter), encoded by the Solute Carrier Family 25 Member 32 (SLC25A32) gene [35]. Subsequently, monoglutamated folates are converted to polyglutamates by the mitochondrial isozyme of Folylpolyglutamate Synthase (FPGS), in order to support the mitochondrial folate cycle [36]. Similarly to the cytosolic pathway, serine is used as a one-carbon donor for the conversion of mitochondrial THF to 5,10-methylene-THF by SHMT2, the mitochondrial SHMT isozyme, which is also B6-dependent [35]. Mitochondrial transport of serine is mediated by the IMM protein sideroflexin 1 (SFXN1) [37]. In addition to serine, glycine, dimethylglycine (DMG), and sarcosine can be used as alternative onecarbon donors. Mitochondrial glycine is derived either by SHMT2-dependent reaction or by direct import from the cytosolic glycine pool by the specialized mitochondrial glycine carrier (GlyC), encoded by SLC25A38 gene [38]. In turn, the mitochondria-localized glycine cleavage system (GCS) mediates the oxidative cleavage of glycine to $\mathrm{CO}_{2}$ and $\mathrm{NH}_{3}$, while the cleaved methylene group is accepted by THF and the latter is reversibly converted to 5,10-methylene-THF [39]. In mammalian liver cells, dimethylglycine and sarcosine, produced by choline oxidation, donate their methylene group to THF, through a process catalyzed by dimethylglycine dehydrogenase (DMGDH) and sarcosine dehydrogenase (SARDH), respectively [40]. Mitochondrial 5,10-methylene-THF can be utilized either for TYMS-dependent dTMP synthesis or for formate production through a series of reactions similar to the cytosolic pathway. Particularly, 5,10-methylene-THF is converted to 5-methenyl-THF and subsequently to 10-formyl-THF by methylene-THF dehydrogenase 2 (MTHFD2) or methylene-THF dehydrogenase 2 like (MTHFD2L) in a process necessitating reduction of NAD+ to NADH. MTHFD2L can use both NAD+ and NADP+ [41]. Recently, it was shown that MTHFD2 is required for de novo purine synthesis in mice and it is activated downstream of mTORC1 in an ATF4-depedent manner [42]. Moreover, serine acts as a source for NADH generation through the mitochondrial OCM. Specifically under conditions of impaired mitochondrial respiration, OCM-derived NADH is no longer consumed through the electron transport chain, thus leading to its aberrant accumulation and toxicity $[43,44]$. The 10 -formyl-THF is subsequently converted to formate by methylene-THF dehydrogenase 1 like (MTHFD1L). Mitochondrial formate is then exported and incorporated to the cytoplasmic formate pool, which can be converted back to 10-formyl-THF and facilitate purine synthesis [26]. Importantly, due to its ability to interfere with mitochondrial respiration (inhibition of cytochrome c oxidase) [45], formate has to be rapidly effluxed from mitochondria, although the identification of a specialized formate exporter is still pending. Apart from formate synthesis, mitochondrial 10-formyl THF can be converted to THF by mitochondrial aldehyde dehydrogenase 1 family member L2 (ALDH1L2) [28] or it can be processed by methionyl-tRNA formyltransferase (MTFMT) 
to generate formylmethionyl-tRNAs (f-Met $\mathrm{tRNAs}$ ), thus promoting mitochondrial protein synthesis [46]. A recent study in yeast cells showed that autophagy is required for preserving adequate levels of serine in mitochondria and for efficient Met-tRNA formylation [47]. Additionally, given that mitochondria lack MAT activity, mitochondrial import of cytosolic $\mathrm{SAM}$ is required to support mitochondrial methylation reactions. S-Adenosylmethionine Mitochondrial Carrier Protein (SAMC), encoded by the SLC25A26 gene, mediates SAM transport into the mitochondrial matrix $[48,49]$. Mitochondrially imported SAM was recently shown to be specifically required for Complex I protein methylation and stability as well as iron sulfur cluster assembly [50].

Although cytosolic and mitochondrial branches are comprised of similar enzymatic reactions, which are often reversible, it is well accepted that they are uni-directionally regulated. Particularly, serine catabolism is favored in mitochondrial compartments, while serine synthesis is favored in the cytosol. The directionality of each pathway relies on the differential abundance of $\mathrm{NAD}(\mathrm{P}) \mathrm{H}$ and $\mathrm{NAD}(\mathrm{P})+$ in the different compartments: Reduced $\mathrm{NAD}(\mathrm{P}) \mathrm{H}: \mathrm{NAD}(\mathrm{P})+$ ratio in mitochondria favors the activity of MTHFD2/ MTHFD2L enzymes towards 10-formyl THF formation and formate synthesis, while augmented NADPH:NADP+ ratio favors the activity of MTHFD1 towards formate catabolism and 5-10-methylene THF synthesis, which is required for the subsequent serine production [1].

The importance of the mitochondrial one-carbon pathway in preserving cytosolic folate is highlighted by a recent study conducted in mammalian cell lines. Ablation of mitochondrial folate metabolism by knocking down SHMT2 or MTHFD1L results in the elimination of cytosolic THF due to reversal of the cytosolic pathway towards formate formation [51]. In addition, products of mitochondrial metabolism, including ATP and other tricarboxylic acid (TCA) cycle metabolites, as well as products of mitochondrial OCM, including formate and serine-derived glycine, are required for cytosolic purine synthesis [52]. Notably, super-resolution microscopy has revealed that purinosomes are in close proximity to mitochondria, suggesting that they are actively positioned near centers of high ATP and metabolite abundance. Particularly, the same study provided evidence that mechanistic target of rapamycin (mTOR) governs the spatiotemporal control of purine synthesis [53].

\section{One-Carbon Metabolism in Aging}

OCM fine-tunes the abundance of critical metabolites in the cell, thereby regulating cell survival, growth, division, and stress response. It is known that metabolic dysregulation correlates and significantly contributes to several diseases, such as cardiovascular diseases, cancer, and inflammation, ultimately leading to increased frailty and death. Furthermore, signaling pathways such as caloric restriction (CR), reduced nutrient sensing, reduced insulin/insulin-like growth factor (IGF)-FOXO signaling, mTOR-AMP-activated protein kinase (AMPK) signaling, or proteostatic stress response pathways (endoplasmic reticulum (ER) unfolded protein response $\left(\mathrm{UPR}^{\mathrm{ER}}\right)$, mitochondrial UPR (UPR ${ }^{\mathrm{mt}}$ ), integrated stress response (ISR), autophagy, DNA damage response (DDR)) often modulate metabolic procedures within cells and across tissues to improve health span and lifespan. Therefore, OCM which lies at the core of cellular metabolism, is expected to be a common denominator of these pathways, ultimately impacting aging and disease. In the following paragraphs we will discuss how several key metabolites of OCM or metabolic branches that directly interact with OCM pathways may associate with aging (summarized in Table 1). 
Table 1. Genetic and environmental manipulations that impact lifespan via modulation of one-carbon metabolism and associated pathways. CLS, chronological lifespan; RLS, replicative lifespan; NAC, $\mathrm{N}$-Acetyl Cysteine; CR, caloric restriction; GSH, glutathione; MTHF5, 5-methyl-tetrahydrofolate.

\begin{tabular}{|c|c|c|c|}
\hline Genetic Manipulation & $\begin{array}{l}\text { Environmental } \\
\text { Manipulation } \\
\end{array}$ & Effect on Lifespan & References \\
\hline \multicolumn{4}{|l|}{ Yeast } \\
\hline & Methionine restriction & CLS extension & {$[54,55]$} \\
\hline met2 deletion & & CLS extension & {$[56,57]$} \\
\hline met15 deletion & & CLS extension & {$[56,57]$} \\
\hline met3 deletion & & RLS extension & {$[58]$} \\
\hline sam1 deletion & & RLS extension & {$[58]$} \\
\hline \multirow[t]{2}{*}{ cys4 deletion } & & CLS extension & {$[59]$} \\
\hline & $\mathrm{H}_{2} \mathrm{~S}$ & CLS extension & {$[60]$} \\
\hline gsh1 deletion & $10 \%$ glucose & CLS shortening & [61] \\
\hline \multicolumn{4}{|l|}{ Nematodes } \\
\hline & sulfamethoxazole & Extension & {$[62]$} \\
\hline$d h f r-1$ RNAi & & extension & {$[63]$} \\
\hline tyms-1 RNAi & & extension & {$[63,64]$} \\
\hline daf-2(e1370) & MTHF5 supplementation & $\begin{array}{l}\text { Reverses longevity } \\
\text { of daf-2 mutants }\end{array}$ & {$[63]$} \\
\hline mel-32 RNAi & & extension & {$[65]$} \\
\hline sams-1 RNAi & & extension & {$[66,67]$} \\
\hline \multirow[t]{4}{*}{ sams-5 RNAi } & & extension & {$[67]$} \\
\hline & Glycine supplementation & extension & {$[65,68]$} \\
\hline & Serine supplementation & extension & {$[65,68]$} \\
\hline & Metformin & extension & {$[69]$} \\
\hline sams-1 mutant & Metformin & $\begin{array}{l}\text { Reverse of metformin's } \\
\text { benefits }\end{array}$ & [69] \\
\hline \multirow[t]{2}{*}{ metr-1 mutant } & Metformin & $\begin{array}{l}\text { Reverse of metformin's } \\
\text { benefits }\end{array}$ & {$[69]$} \\
\hline & $\mathrm{H}_{2} \mathrm{~S}$ & extension & {$[70,71]$} \\
\hline \multirow[t]{5}{*}{ cbs-1 overexpression } & & extension & {$[60]$} \\
\hline & NAC from day 3 & extension & {$[72]$} \\
\hline & NAC from L4 & shortening & {$[73]$} \\
\hline & taurine & extension & {$[68]$} \\
\hline & Acivicin (GSH restriction) & extension & [73] \\
\hline \multicolumn{4}{|l|}{ Files } \\
\hline \multirow[t]{2}{*}{ GNMT overexpression } & & extension & [74] \\
\hline & Methionine restriction & extension & {$[75,76]$} \\
\hline Sams depletion & & extension & {$[74]$} \\
\hline Cbs overexpression & & extension & {$[77]$} \\
\hline Cbs depletion & Caloric restriction & Reversed CR-driven longevity & {$[78]$} \\
\hline Gclc overexpression & & extension & [79] \\
\hline Gclm overexpression & & extension & [79] \\
\hline dAhcyL1/dAhcyL2 suppression & & Extension & {$[80]$} \\
\hline
\end{tabular}


Table 1. Cont.

\begin{tabular}{|c|c|c|c|}
\hline Genetic Manipulation & $\begin{array}{l}\text { Environmental } \\
\text { Manipulation }\end{array}$ & Effect on Lifespan & References \\
\hline \multicolumn{4}{|l|}{ Mammals } \\
\hline $\begin{array}{l}\text { Transgenic growth } \\
\text { hormone mice }\end{array}$ & $\begin{array}{l}\text { Supplementation of several } \\
\text { forms of folate }\end{array}$ & Extension & [81] \\
\hline wt & $\begin{array}{l}\text { Supplementation of several } \\
\text { forms of folate }\end{array}$ & Extension & [81] \\
\hline Female SHR mice & metformin & Extension & [82] \\
\hline Rats, mice & Dietary Methionine restriction & Extension & [83-85] \\
\hline $\begin{array}{l}\text { Tissue-specific taurine } \\
\text { transporter depleted mice }\end{array}$ & & Shortening & [86] \\
\hline \multicolumn{4}{|l|}{ Humans } \\
\hline C667T MTHFR & & $\begin{array}{l}\text { Associates with decrease in } \\
\text { all-cause mortality }\end{array}$ & {$[87,88]$} \\
\hline
\end{tabular}

\subsection{Folate Cycle in Aging}

Folate blood levels decrease in the elderly. However, little is known regarding the causal association between aging and folate deficiency. In mammalian animal models, folate metabolism has been reported to affect aging-related phenotypes. Comparison of aspects of folate metabolism between young and aged rats showed that aging affects folate levels in the serum (approximately 50\% reduction) but does not have an effect in liver folate content [89]. Folate deprivation in diet leads to a decrease in folate levels both in the serum and the liver in both age groups. Moreover, folate deprivation is associated with increased poly-glutamate chain length in both young and old rats [89]. Folate-deprived mice exhibit circadian oscillation impairments similar to the ones exhibited by older individuals [90]. Mice fed on a folate-deprived diet from weaning until 8 and 10 months of age exhibit manifestations of brain aging such as short-term memory impairment, altered SAM metabolism, and acetylcholine levels. Moreover, these mice show differential expression of Presenillin-1, OCM genes, and epigenetic enzymes, possibly compensating for the reduced folate intake [91]. On the contrary, supplementation of several folate forms, in the context of a more complex dietary supplement, shows beneficial effects on lifespan in wt and transgenic growth hormone mice (TGM), which have been used as models for accelerated aging [81].

The most common polymorphism of the MTHFR gene in humans is the C677T (Ala222 $\rightarrow$ Val), which produces an enzyme with reduced function. MTHFR mediates the conversion of 5,10-methylene-THF into 5-methyl-THF, and C677T polymorphism is accompanied with low folate and high Hcy levels. Interestingly, this polymorphism inversely correlates with several types of colorectal cancer and AD [92]. Moreover, C667T MTHFR displays a slightly beneficial effect on all-cause mortality in two large population studies $[87,88]$.

Invertebrates are also folate auxotrophs. Integrated proteomic and metabolomic analyses in the eye of aged Drosophila melanogaster flies revealed that folate and purine metabolic pathways are affected the most, with strong downregulation of pteridine-containing metabolites [93]. The soil nematode Caenorhabditis elegans feeds on live Escherichia coli bacteria and depends on them for folate uptake. Pharmacological inhibition of folate synthesis in this nematode/bacteria system leads to increased nematode lifespan [62]. However, inhibition of $C$. elegans genes for folate uptake or polyglutamase activity does not exhibit significant benefits on nematode longevity [94]. Moreover, the antidiabetic drug metformin alters nematode lifespan by impacting bacterial folate and methionine metabolism. The effects of metformin on nematode longevity are reversed in worm mutants of MAT and MTR genes [69,95]. Glycine and serine supplementation also leads to extended lifespan in worms $[65,68]$. This extension is mediated by the methionine cycle as it is reversed in MAT (sams-1) and MTR (metr-1) mutants [65]. Interestingly, transcrip- 
tional activation of glycine metabolism and folate-dependent OCM is a prominent trait of longevity shared between seemingly different longevity paradigms [65]. Recently, it was reported that folate intermediates undergo extensive quantitative changes that are often common among long-lived nematode mutants [63]. Folate, THF, and 5,10-methylene-THF are increased while 5-methyl-THF, 10-formyl-THF, and 5,10 methenyl-THF are robustly and reproducibly decreased. Similar data were obtained when the DHFR enzyme was genetically suppressed in nematodes, also leading to lifespan extension. Notably, supplementation with 5-methyl-THF reversed longevity of long-lived mutants, of reduced insulin signaling (rIIS), inherently caloric restricted, and mitochondrial mutants, while folic acid supplementation did not alter lifespan of wt nematodes [63]. Conclusively, increasing reports suggest that altered OCM may be a shared metabolic trait of longevity.

Unrepaired DNA damage that accumulates from development throughout adult-hood is correlated and may drive the aging process. Folate deficiency leads to imbalance in DNA precursors and misincorporation of uracil into DNA, causing DNA instability [96,97]. Moreover, gamma-irradiation, a well-established DNA damaging factor, leads to progressive depletion of folates due to their increased consumption for production of nucleotide bases [98] and the oxidative splitting of the folate molecule to pterin and p-aminobenzoylglutamic acid [99]. In mice, DHFR and TYMS activity peaks 92 and 76hours after whole body gamma irradiation, respectively, while MTHFR activity remains almost unchanged [100]. Folate deficiency in rats impairs DNA excision repair in colonic mucosa [101]. Additionally, aging affects folate levels and uracil misincorporation in the colon [102]. These findings pertinent to the interaction of folate metabolism with DNA synthesis and repair raise the possibility that OCM could affect the rate of aging by impacting genomic integrity. However, further research is required to elucidate the cause-and-effect relationship of folate metabolism, genomic integrity, and aging.

\subsection{Methionine Cycle in Aging}

CR without malnutrition is a universal strategy to increase lifespan across species [103]. A growing body of evidence supports that restriction of dietary proteins and amino acids, rather than carbohydrate and lipids, determines longevity upon CR [104]. Among them, methionine is an essential amino acid whose restriction from diet has been mostly successful in extending lifespan in yeast, invertebrate models, and rodents [55,75,76,83-85,105]. Genetic manipulations leading to methionine restriction yield similar results [56-58,69]. Interestingly, a comparative study of plasma methionine metabolic profile among 11 mammalian species whose lifespans range from 3.5 to 120 years revealed a correlation of longevity with reduced methionine and cystathionine levels [106]. Methionine restriction (MR) is proposed to reproduce some of the metabolic consequences of CR. For example, MR, like $\mathrm{CR}$, leads to lower rates of mitochondrial reactive oxygen species (ROS) production and oxidative damage on mitochondrial DNA (mtDNA) in mice [107]. Suppression of the growth hormone (GH)/IGF somatotropic axis has been reported in rodents upon MR [83,104], leading to in vivo insulin sensitivity, reduced hepatic lipogenesis, and white adipose tissue lipid remodeling. Interestingly, the hepatic fibroblast growth factor FGF21, a component of the ISR pathway, mediates part of the effects [108-110]. Moreover, MR activates the phosphorylation of eukaryotic translation initiation factor 2A (EIF2A) in a general control nonderepressible 2 (GCN2) kinase-independent mechanism [111]. Reduction of SAM levels upon MR enables the SAM sensor upstream of mTORC1 (SAMTOR) to bind gap activity toward rags 1 (GATOR1) and thereby inhibit mTORC1 signaling [112]. Recently it was shown that dietary MR in mice leads to a rapid decrease in hepatic methionine, leading to inhibition of the translation initiation ternary complex, thereby slowing down protein translation. Moreover, MR in mice leads to ISR induction in a mTORC1- and activating transcription factor 4 (ATF4)-dependent manner [113]. A methionine-supplemented diet has been correlated with chromosomal and DNA damage in murine peripheral blood while MR rescues from basal DNA damage in murine liver [114]. Longevity in several organisms is mediated by nutritional, environmental, or genetic interventions that activate autophagy [115]. MR 
extends chronological lifespan (CLS) of yeast in an autophagy-dependent manner [56]. Interestingly, mitochondria-specific autophagic clearance, mitophagy, was reported to mediate the beneficial effects of MR on yeast CLS [54]. Finally, methionine supplementation can reverse the beneficial effects of glucose restriction on yeast replicative lifespan (RLS), suggesting that intracellular methionine may coordinate the outcome of several longevity-promoting pathways [116].

All these longevity-promoting signaling cascades regulate metabolic adaptation of cells and tissues in response to MR. However, apart from these pathways, methionine metabolism can affect longevity through impacting SAM availability. As mentioned above, 5-methyl-THF feeds into the methionine cycle to produce methionine and SAM. In $D$. melanogaster, SAM levels increase with age and enhancing its catabolism by glycine$\mathrm{N}$-methyltransferase (GNMT) overexpression, extends longevity [74]. Moreover, GNMT expression levels are enhanced in flies and mice upon reduced insulin/IGF signaling (rIIS), while GNMT is required for full rIIS longevity [117]. Reduction of SAM synthesis upon genetic inhibition of SAM synthase, the homolog of mammalian MAT, has also been proven beneficial for the lifespan of worms and flies [66,74]. Specifically in nematodes, suppression of sams-1 or sams-5 leads to longevity, possibly through distinct mechanisms $[66,67]$. Moreover, the SAM:SAH ratio is markedly increased, while liver and kidney gnmt mRNA levels are decreased in the short-lived growth hormone transgenic mice (GH-Tg). Methionine restriction reverses the SAM:SAH ratio in GH-Tgs but not to wt levels [118]. In flies, genetic suppression of two out of three AHCY homologs, systemically or in a tissue-specific manner, reduces age-related SAH accumulation and leads to lifespan extension [80].

The availability of SAM is a critical denominator of methylation reactions on DNA, RNA, and proteins, and represents a key conduit linking cellular metabolism to the epigenetic landscape. DNA methylation takes place in CpG dinucleotides, by the addition of a methyl group on the position $5^{\prime}$ of the cytosine pyrimidine ring. Methylation also occurs in the $\mathrm{CpA}, \mathrm{CpT}$, and $\mathrm{CpC}$ sites, although it is restricted to specific cell types such as neurons, glia, and pluripotent stem cells [119]. More rarely, it takes place in adenosine, producing $N^{6}$-methyladenosine $\left(\mathrm{m}^{6} \mathrm{~A}\right)$ [120]. DNA methylation is a fundamental signature of gene repression and has been used for the development of accurate age prediction tools, the so-called epigenetic clocks [121-123]. DNA methylation patterns are the cumulative result of de novo DNA methylation reactions, mediated by DNA methyltransferases 3A (DNMT3A) and B (DNMT3B) and maintenance of DNA methylation, mediated primarily by DNMT1 [120]. Interestingly, DNA methylation seems to decrease with age, with several human tissues showing similar age-related alterations [113]. Similarly, age-dependent hypomethylation is observed in rats and mice [124,125]. Moreover, age-associated methylation changes are suppressed in the long-lived Ames dwarf mice, which are deficient in the GH/IGF somatotropic axis [126]. DNA methylation changes relative to the exceptional longevity of bats occur primarily on innate immunity and tumorigenesis genes, suggesting that they exhibit enhanced immune response and cancer suppression [127]. Mitochondrial dysfunction, which escalates during aging, can also impact DNA methylation through methionine metabolism, as shown in a cell culture model of induced mtDNA depletion [128].

Histone methylation cooperates with DNA methylation to maintain chromatin epigenomic landscape. Imbalance of SAM:SAH ratio affects histone methylation, thereby modulating longevity in different species $[105,129]$. Suppression of transcription-activating histone marks (such as H3K4) or overexpression of suppressive histone marks (H3K27) are usually linked to longevity in invertebrates. Genetic perturbations of methyltransferases can impact longevity across species [105]. In mammals, further studies are required to decipher the role of histone methylation on lifespan.

\subsection{Homocysteine in Aging}

Hcy is produced intracellularly in its reduced form and then it is exported by endothelial cells into the blood circulation where it is mostly oxidized to disulphides [130]. 
Elevation of Hcy plasma concentration represents a well-established risk factor for several age-related diseases such as cardiovascular dysfunction and stroke, while it also contributes to poor wound healing, loss of regenerative ability, and decline in renal and cognitive function [131]. Several factors can be linked to increased Hcy level. Low dietary folate and cobalamin (vitamin B12) intake leads to increased Hcy levels since they are required for methionine regeneration from Hcy. Renal dysfunction often arising with age affects proper removal of Hcy, leading to elevation of its serum levels [132]. Moreover, administration of certain anticonvulsant drugs or methotrexate, the specific inhibitor of DHFR, impairs folate metabolism, leading to the rise of serum Hcy [133,134]. As Hcy lies at the center of multiple metabolic reactions that regulate its conversions, dysfunction in the involved metabolic enzymes may impact its abundance. Therefore, dysfunction of MTR, MTRR, and MTHFR, which are required for Hcy remethylation to methionine, correlate with increased Hcy levels. Another pathway of Hcy remethylation to methionine is mediated by betaine and BHMT. Betaine is an amino acid derivative absorbed from diet and converted to trimethylglycine in enterocytes. Betaine is used as an osmolyte and a methyl donor for Hcy remethylation [131]. Interestingly, serum betaine is inversely correlated with weight, BMI, and body fat [135] while it linearly associates with a reduced risk of having low lean mass [136]. BHMT contains three cysteine residues that coordinate one $\mathrm{Zn}$ atom. Long-term exposure to oxidative conditions leads to cysteine oxidation, which hinders Zn binding and thereby enzyme activity in vitro [83].

\subsection{Transsulfuration Pathway in Aging}

When Hcy is not recycled to methionine it is channeled irreversibly through the transsulfuration pathway. In the canonical transsulfuration pathway, CBS mediates the condensation of Hcy and serine to form cystathionine and water. Depletion of the yeast CBS homolog cys4 extends chronological lifespan (CLS) [59]. Ubiquitous or neuron-specific overexpression of CBS extends the lifespan of well-fed flies, while a functional CBS is required for lifespan extension upon dietary restriction $[77,78]$. In nematodes, robust proliferation of adult germline stem cells delays reproductive aging and leads to lifespan extension upon cold exposure. Interestingly, this longevity is mediated by prostaglandin E2 signals that induce cross-tissue activation of $c b s-1$ gene and hydrogen sulfide $\left(\mathrm{H}_{2} \mathrm{~S}\right)$ production in the intestine [137]. Moreover, $c b s-1$ overexpression in the nematode intestine or body wall muscles extends lifespan at standard $\left(20^{\circ} \mathrm{C}\right)$ and high $\left(25^{\circ} \mathrm{C}\right)$ rearing temperatures [137]. A recent study reported a unique plasma metabolic profile of centenarians characterized by increased transsulfuration pathway intermediates such as Hcy, cystathionine, and taurine [138]. When cysteine is used instead of serine, the products of CBS catalysis are cystathionine and $\mathrm{H}_{2} \mathrm{~S}$. There is increasing evidence for the role of $\mathrm{H}_{2} \mathrm{~S}$ on aging regulation, although its effects on different species are contradictory $[60,139,140]$. Mammalian species with increased longevity have reduced $\mathrm{H}_{2} \mathrm{~S}$ blood levels and liver CBS activity [141]. However, exogenous supplementation of $\mathrm{H}_{2} \mathrm{~S}$ extends the lifespan of C. elegans by activating skinhead-1 (SKN-1) transcription factor $[70,142]$ and in a CRindependent manner [67]. Recently it was shown that dietary restriction in mice leads to a CSE-dependent increase in $\mathrm{H}_{2} \mathrm{~S}$ biosynthesis that leads to tissue-specific alterations in protein persulfidation [143]. Whether these changes in protein persulfidation are linked to longevity and stress resistance triggered by dietary restriction is a question that begs to be answered.

Another product of the transsulfuration pathway is taurine. Taurine is a conditionally essential beta-amino acid that is endogenously produced from cysteine, but mammals need to supplement its levels through dietary intake. It is one of the most abundant amino acids in the vertebrate brain in regions such as the cerebellum and the cortical cortex [144]. In humans, taurine supplementation associates with lower blood pressure, improved vascular function, reduced risk for ischemic heart disease, and other health benefits [145]. In mice, tissue-depletion of taurine in a taurine transporter knockout mutant leads to skeletal muscle deterioration and shorter lifespan in both male and female populations [86]. 
Taurine supplementation in nematodes leads to an extended lifespan [68], while in flies it rescues age-associated intestinal stem cell hyperproliferation and gut hyperplasia by eliminating UPR ${ }^{\mathrm{ER}}$ stress [146].

\subsection{Glutathione in Aging}

GSH is the main intracellular redox buffer. It is composed of three amino acids, glycine, cysteine, and glutamic acid and it exists in a reduced and oxidized form. Cysteine produced from the transsulfuration pathway is usually the rate-limiting amino acid for GSH biosynthesis and GCL catalyzes the rate-limiting step in GSH biosynthesis. Once synthesized, GSH can be used as a co-substrate for glutathione peroxidase (GPX)-catalyzed reactions, mediating removal of hydrogen peroxide $\left(\mathrm{H}_{2} \mathrm{O}_{2}\right)$ and lipid hydroperoxides and producing its oxidized form, the glutathione disulfide (GSSG). Reduction of GSSG back to GSH is catalyzed by glutathione reductase and uses NADPH [147]. The Redox Theory of aging proposed that longevity is modulated by the cellular redox state, which is reflected in the ratios of GSH/GSSG and NADP ${ }^{+} / \mathrm{NADPH}$ levels, among others [148]. Redox buffering systems do not only rescue macromolecules from oxidative damage but also regulate the levels of ROS molecules, which act as signaling components that modulate aging [149]. In yeast, depletion of Gsh1 gene impacts CLS depending of the dietary glucose levels [61]. In D. melanogaster, systemic or neuronal overexpression of GCL catalytic or modulatory subunits increases glutathione content and extends their lifespan [79]. However, in worms, GSH supplementation has yielded contradicting results. Earlier studies have shown that small GSH concentrations prolongs longevity [72] while recently it was reported that prolonged supplementation of adult worms with dietary thiols such as N-Acetyl Cysteine (NAC) and GSH accelerated their aging [73]. Differences in the timepoint of NAC treatment could explain this discrepancy. Specifically, when NAC is provided from day three of adulthood onwards it is beneficial, while when it is provided just before (L4 larvae) and throughout adulthood it is not. This suggests that ROS could mediate a pro-longevity signal early in adulthood. If this signal is lost by early NAC supplementation, then NAC accelerates aging. If NAC is provided later in adulthood, it protects from age-related oxidative damage and thus it prolongs longevity. GSH blood levels drop in obese mice and humans; however, $\mathrm{GClm}^{-} /{ }^{-}$mice. Which lack the GCL enzyme, are protected against obesity and insulin resistance [150]. In humans, GSH supplementation has yielded poor benefits for the elderly, likely due to the instability of the molecule when transported through the gastrointestinal tract. Alternative approaches include supplementation with GSH precursor amino acids such as glycine and NAC or glycine and cysteine. This approach has yielded promising results in the potential treatment of age-related decline in the elderly [151-153].

\section{One-Carbon Metabolism and Neurodegeneration}

OCM, as a central metabolic hub for the production of critical metabolites that serve as building blocks for cellular growth and replication, it holds a very important role in regulating developmental processes and tumorigenesis [154-157]. Folic acid is typically prescribed to pregnant women to facilitate neuronal development of the fetus and prevent neural tube defects $[158,159]$. Nevertheless, its implication in preserving the integrity of post-mitotic neuronal cells is also under intense investigation. Many epidemiological studies associate reduced levels of folate with cognitive decline in the elderly [160-162]. However, whether these phenomena are causatively linked is not yet clear. Accumulating studies have associated OCM with the onset and development of neurodegenerative diseases. In the following section we are going to analyze how impairment in OCM contributes to Azheimer's disease (AD) and Parkinson's disease (PD), the most frequent types of age-related neurodegeneration.

\subsection{One-Carbon Metabolism in the Pathogenesis of Alzheimer's Disease}

$\mathrm{AD}$ is one of the most prevalent types of dementia in the elderly worldwide. AD patients display progressive degeneration of neurons in the cerebral cortex and subcortical 
regions, including the hippocampus, a region associated with long-term memory storage. Extracellular deposition of aggregated amyloid-beta plaques, as well as intracellular formations of hyper-phosphorylated Tau proteins, known as neurofibrillary tangles, are suggested to be the main hallmarks for AD pathogenesis [163]. Several prospective studies during the last decades support that diet enriched in folates and vitamins is protective against AD pathogenesis [164-169].

Perturbations in OCM, as a consequence of inadequate dietary folate uptake, have been associated with initiation and progression of AD. Particularly, increased plasma Hcy and concomitant decrease of the SAM:SAH ratio in AD-affected brain samples imply disruption in methylation pathways, which lead to epigenome-dependent changes in the expression of disease-related factors [170-172]. Reducing folate and vitamin B12 uptake in neuroblastoma cell lines diminishes SAM levels and reduces methylation in promoter regions of beta-site amyloid precursor protein cleaving enzyme 1 (BACE1) and presenilin 1 (PSEN1) genes [173]. Both genes encode for proteins that participate in the amyloidogenic cleavage of amyloid protein precursor (APP) [174]. Demethylation enhances BACE1 and PSEN1 expression and promotes $\mathrm{A} \beta$ generation [173]. Hyperhomocysteinemia, imbalanced SAM:SAH ratio, and hypomethylation of BACE1 and PSEN1 genes were also confirmed in vivo, in mouse AD models upon deprivation of folate and vitamins B6 and B12. Remarkably, in the particular study, the affected mice displayed intra-neuronal $A \beta$ accumulation and early manifestation of cognitive decline prior to extracellular A $\beta$ deposition [175]. SAM administration in AD mouse models at this early stage restores global DNA and $B A C E 1$ promoter methylation, reduces intra-neuronal and extracellular $\mathrm{A} \beta$ deposition, and reverses cognitive deficits in AD mouse models [176]. However, further studies are required for clarifying the association of hypomethylated $B A C E 1$ regulatory regions and AD development, as results in post-mortem AD brain samples are contradicting $[177,178]$. On the contrary, despite the existence of limited contradicting studies regarding PSEN1 gene, in vitro and in vivo studies have associated B-vitamin deficiency with enhanced PSEN1 expression due to hypomethylation of its promoter $[179,180]$. Additionally, reduced CpG and non-CpG methylation patterns of PSEN1 genomic regions have been reported in post-mortem human brains, although they do not correlate this phenotype with disturbances in OCM [181]. A point to be noted is that dietary supplementation with folic acid is also protective against $A \beta$ generation by favoring $\alpha$-secretase over $\beta$-secretase activity. Although mechanistic insights regarding DNA methylation are currently missing, it is reported that miR-126-3p, a miRNA that specifically targets the $\alpha$-secretase A Disintegrin And Metalloproteinase Domain 9 (ADAM9), is significantly downregulated upon folic acid supplementation [182]. Deregulated DNA methylation status in AD-related contexts has also been attributed to differential expression and activity of specific methyltransferases and demethylases. Specifically, in vitamin B-deficient neuronal cells and AD mice models, expression and activity of Methyl-CpG Binding Domain Protein 2 (MBD2) demethylase are significantly increased. This phenotype is reversed upon SAM supplementation. Similarly, the activity of de novo methyltransferases DNMT3A and DNMT3B is increased in SAM-supplemented neuroblastoma cells and AD mice models [183]. It is noteworthy that folic acid administration in mice protects against $\mathrm{A} \beta$ accumulation by enhancing DNMT1 methyltransferase activity in a dose-dependent manner and reducing PSEN1 and APP expression through methylation of their promoter regions [184], although the association of APP gene methylation with AD pathogenesis needs further validation, since several studies have reported non-significant changes $[177,185]$. Additionally, genetic polymorphisms in MTRR and DNMT3A genes have been associated with reduced D-loop methylation of mtDNA in AD contexts [186]. In accordance, the MT-ND1 gene, which encodes for NADH-ubiquinone oxidoreductase chain 1, was found significantly hypomethylated in AD brain samples [187]. Generally, the findings regarding differential DNA methylation of AD-related genes should be interpreted with caution, as methylation status may be context dependent and vary during AD progression stages. 
Discrepancies in OCM have also been implicated in Tau phosphorylation and in the formation of pathogenic neurofibrillary tangles mainly through inhibition of Proteinphosphatase 2A (PP2A). PP2A is the main serine/threonine phosphatase involved in dephosphorylation of Tau protein in the brain and, thus, is considered to have a neuroprotective role against AD. Post-translational methylation of its catalytic subunit C positively regulates PP2A activity by stimulating its stability and substrate specificity [188]. Numerous studies have demonstrated reduced PP2A methylation in post-mortem AD brain tissues, in AD mouse models, as well as in neuronal cell lines [189-194]. Folic acid or SAM supplementation rescues PP2A hypomethylation and alleviates AD-related pathology [192,195,196]. A very recent study showed that methylated PP2A promotes the non-amyloidogenic cleavage of APP through interaction with non-receptor protein kinase Fyn [197]. Additionally, mice deficient in MTHFR, the enzyme that catalyzes the conversion of 5,10-methylene-THF to 5-methyl-THF, display decreased levels of methylated PP2A and concomitantly reduced expression of its methyl-transferase leucine carboxyl methyltransferase 1 (LCMT-1). The particular effects are aggravated upon folate deficiency [198]. An alternative mechanism for PP2A hypomethylation was suggested in a study conducted in rats upon intravenous administration of Hcy. High Hcy levels in the hippocampus enhances Tau phosphorylation by activating the PME methylesterase, which specifically demethylates PP2A and exacerbates Tau phosphorylation [199].

A growing amount of research has correlated disturbances in OCM and particularly hyperhomocysteinemia with induced oxidative stress in AD contexts [200-205]. Inadequate dietary uptake of folates and B vitamins [206], mutations in the gene of the rate-limiting enzyme MTHFR [207], as well as impairment in the transsulfuration pathway [208-210] are suggested to contribute to elevated Hcy levels in the blood of AD patients or in respective AD models. The major mechanism through which hyperhomocysteinemia induces oxidative stress and neurotoxicity is suggested to be the dysregulation of calcium homeostasis through overstimulation of NMDA receptors [200,211-214]. Hyperhomocysteinemia has also been linked to DNA damage-induced hypersensitivity to excitotoxicity and apoptosis in rat hippocampal neurons [215]. In accordance, patients deficient in CBS, a core enzyme for the transsulfuration of Hcy to cystathionine, display increased DNA damage due to Hcy accumulation [216]. Recent studies highlight the importance of adequate vitamin B12 intake in alleviating ROS-mediated oxidative damage and A $\beta$-induced paralysis in C. elegans AD models $[217,218]$. Importantly, they showed that this protective effect of B12 relies on its ability to promote Hcy remethylation by acting as a cofactor for MTR in the methionine cycle [218]. Interestingly, betaine supplementation in C. elegans is also protective against $\mathrm{A} \beta$-induced toxicity, although this mechanism does not involve Hcy remethylation, but rather depends on the CBS-mediated transsulfuration pathway [219]. Conclusively, therapeutic strategies aiming to eliminate Hcy levels either through the methionine cycle or through the transsulfuration pathway have emerged to be beneficial for alleviating oxidative stress in AD. Deficiency in GSH, a well-established antioxidant produced by Hcy transsulfuration, is suggested to exacerbate AD-related oxidative stress and contribute to cognitive decline in AD patients [220-223].

\subsection{One-Carbon Metabolism in the Pathogenesis of Parkinson's Disease}

PD is the second most prevalent age-related neurodegenerative disorder after AD. PD patients mainly display motor-related symptoms, including constant tremors, bradykinesia, impaired balance, and enhanced rigidity in their limbs and trunk. Motor dysfunction in PD develops by the progressive loss of dopamine-producing neurons of the substantia nigra (SN), a basal ganglia structure of the midbrain, predominantly associated with movement. Another major hallmark is the formation of intraneuronal protein clumps mainly comprised of alpha-synuclein $(\alpha S Y N)$ and ubiquitin [224]. Although most PD cases are sporadic, mutations in several genes have been associated with PD onset. Among these, mutations in $\alpha$ SYN-encoding gene (SNCA), vacuolar protein sorting associated protein 35 (VPS35), and leucine-rich repeat kinase 2 ( $L R R K 2)$ are the main causes of monogenic PD inherited in 
an autosomal dominant manner. There have also been identified autosomal-recessive cases of PD, mostly linked to mutations in PARK2 (encoding for Parkin), phosphatase and tensin homolog-induced putative kinase 1 (PINK1) and PARK7 (encoding for DJ-1) genes [225].

Numerous studies have demonstrated a potential role of OCM in the development of PD [226]. In accordance with AD, elevated plasma Hcy is evident in approximately $30 \%$ of PD patients and is suggested to be involved in the onset and progression of PD [227]. Hyperhomocysteinemia in PD patients may be aggravated due to the frequent administration of L-DOPA as a treatment to replenish dopamine loss. Particularly, L-DOPA acts as a methyl acceptor by using methyl groups from SAM, leading to increased SAH levels and subsequent elevation in Hcy [228]. An alternative mechanism for L-DOPA-mediated elevation in Hcy is the sequestration of vitamin B6, which leads to B6 deficiency and the subsequent inactivation of key enzymes participating in the transsulfuration pathway (CBS, CSE) $[229,230]$. Thus, it is suggested that the administration of folic acid or B vitamins may be beneficial for PD patients treated with L-DOPA [231]. Apart from the L-DOPA-dependent increase in Hcy, reduced dietary folate as well as impairment in the pathways that are involved in Hcy elimination (methionine cycle, transsulfuration pathway, Hcy release in the extracellular space) may also contribute to hyperhomocysteinemia in PD. Several case control and prospective studies show that folic acid and/ or vitamin B deficiency is evident in PD patients and is likely the major determinant of elevated Hcy in PD [232-236]. Interestingly, periodic administration of folic acid in PD patients normalized Hcy levels [237], while high dietary B6 intake was associated with a decreased risk for PD onset [234]. Although the exact roles of folate or B vitamins are still emerging, some previous studies display contradicting results and conclude that there is no association with PD onset and progression [233,238,239]. Furthermore, genetic polymorphisms in genes encoding the rate-limiting enzymes of the methionine cycle, MTHFR, MTR, and MTRR, have been associated with high risk for PD development and are suggested to contribute to hyperhomocysteinemia in PD patients [240-242].

Similarly to AD, several studies provide insights of dysregulated DNA methylation in PD $[243,244]$, suggesting that disturbances in folate metabolism, the indispensable route for SAM production, may account for these epigenetic changes. Analyses of post-mortem PD brains or peripheral blood samples from PD patients show reduced DNA methylation in the promoter region or in intron 1 of SNCA gene, indicating that the particular hypomethylation contributes to elevated SNCA expression [245-247]. Although contradictory results support that hypomethylation of SNCA intron 1 does not interfere with the transcription of the SNCA gene [248], a subsequent study using advanced technical approaches confirmed that the particular methylation is cell-type specific and indeed it regulates SNCA expression [249]. Notably, reduced SAM levels are associated with elevated $\alpha$ SYN platelet formation in PD patients [250]. An interesting mechanism contributing to deregulation of DNA methylation in PD was suggested by a study conducted in post-mortem brain tissues, in neuronal cells as well as in $\alpha S Y N$-transgenic mice. They showed that nuclear levels of the maintenance methyltransferase DNMT1 are reduced due to $\alpha$ SYN-dependent sequestration of DNMT1 to the cytosol [251]. It would be interesting for future studies to investigate whether folate supplementation could rescue universal or SNCA gene DNA hypomethylation in PD contexts by reversing DNMT1 translocation or by enhancing the function of de novo DNMT3A and DNMT3B methyltransferases. However, DNA hypomethylation is not universal in PD contexts, since several genes, including PD-risk genes, are reported to be differentially methylated (and not only hypo-methylated as expected) [243]. These observations point out that there should be selective mechanisms determining hypo- or hypermethylation of specific promoters or genomic regions. In any case, perturbations in the SAM:SAH ratio evident in PD cases [250] surely influence the epigenetic outcomes. Notably, a very recent study showed that mtDNA is significantly hypomethylated in different tissues of PD patients compared to their control counterparts [252], in agreement with a previous report displaying reduced mtDNA D-loop methylation in the SN of PD patients [187]. 
A growing body of evidence has confirmed that mitochondrial dysfunction in conjunction with elevated oxidative stress both contribute to the degeneration of dopaminergic neurons in PD patients [253,254]. Importantly, a pronounced decrease in GSH levels is evident in the SN of PD patients [255]. Whether GSH deficiency is involved in PD aetiology or whether it is a consequence of it remains largely enigmatic. Additionally, it is not well defined whether disturbances in the transsulfuration pathway contribute to reduced GSH levels in PD contexts. Interestingly, inducible knockdown of GCL gene, encoding the ratelimiting enzyme for de novo GSH synthesis, results in selective inhibition of mitochondrial complex I and subsequent mitochondrial dysfunction in dopaminergic SN neurons of transgenic mice. This is mediated by an enhanced nitric oxide (NO)-dependent thiol oxidation event due to GSH loss [256]. Another study conducted in a D. melanogaster PD model showed that Parkin deficiency augments oxidative stress, curtails antioxidant activity, and disturbs mitochondrial function, as monitored by low ATP production. Notably, all these effects are ameliorated upon folic acid supplementation, supporting the beneficial role of folates in relieving PD-related oxidative stress and mitochondrial dysfunction [257]. Furthermore, shRNA against the PD-related PARK7 gene in neuronal cells leads to elevation of oxidative stress and significant reduction in SHMT2 and MTHFD2 genes [258]. Both genes are implicated in mitochondrial serine catabolism and formate synthesis, suggesting that formate deficiency could contribute to PARK7-related PD pathogenesis.

\section{Conclusions and Future Perspectives}

Our knowledge on metabolic adaptations that take place upon aging and neurodegeneration has greatly advanced during the last years, due to the development of new analytical methods. We now appreciate that specific metabolites and metabolic pathways are typically associated with old age and/or disease. OCM is a central metabolic hub and holds a prominent role in the regulation of cellular metabolic status. However, the more we deepen into the complexity of the metabolome, we appreciate the need to further elucidate the relative metabolic fluxes that characterize longevity, aging, and disease. On top of this complexity, tissue-specific and disease-specific contexts should be considered. As these fluxes emerge, new therapeutic strategies will develop to control them in specific tissues and rewire the metabolic profile to the benefit of the tissue and the organism. OCM is a promising target of such therapeutic interventions as it directly responds to dietary inputs and pharmacological compounds. Future studies should determine the exact mechanisms through which OCM could safely combat age-related decline.

Author Contributions: E.L. and C.P. prepared the original draft of the manuscript. E.L., C.P. and N.T. revised and edited the manuscript. All authors have read and agreed to the published version of the manuscript.

Funding: This work was supported by the European Research Council (GA695190- MANNA) and the grant EPHESIAN [(MIS: 5031213), as part of the National Competitiveness, Entrepreneurship \& Innovation operational programme] to N.T. and by the Hellenic Foundation for Research and Innovation (HFRI) and the General Secretariat for Research and Technology (GSRT), under grant agreement No. 1898] to E.L. The APC was funded by GA695190- MANNA.

Institutional Review Board Statement: Not applicable.

Informed Consent Statement: Not applicable.

Data Availability Statement: Not applicable.

Acknowledgments: We gratefully acknowledge the contributions of numerous investigators that we could not include in this review, owing to space limitations.

Conflicts of Interest: The authors declare no conflict of interest. 


\section{Abbreviations}

$\alpha S Y N$ : alpha-synuclein; AD, Alzheimer disease; ADAM9, A disintegrin and metalloproteinase domain 9; AHCY, S-adenosyl-L-homocysteine hydrolase; ALDH1L1, aldehyde dehydrogenase 1 family member L1; ALDH1L1, aldehyde dehydrogenase 1 family member L2; AMP, adenosine monophosphate; AMPK, AMP-activated protein kinase; APP, amyloid protein precursor; ATF4, Activating Transcription Factor 4; ATIC, 5-aminoimidazole-4-carboxamide ribonucleotide formyltransferase/IMP cyclohydrolase; BACE1, beta-site amyloid precursor protein cleaving enzyme 1; BHMT, betaine-homocysteine methyltransferase; CBS, cystathionine beta synthase; CLS, chronological lifespan; CR, caloric restriction; CSE, cystathionine gamma lyase; DDR, DNA damage response; DHF, dihydrofolate; DHFR, dihydrofolate reductase; DMG, dimethylglycine; DMGDH, dimethylglycine dehydrogenase; DNMT1, DNA methyltransferase 1; dTMP, deoxythymidylate; dUMP, deoxyuridylate; EIF2A, eukaryotic translation initiation factor $2 \alpha$; ER, endoplasmic reticulum; FADH2, dihydroflavine-adenine dinucleotide; f-Met tRNA, formylmethionyl-tRNA; FPGS, Folylpolyglutamate Synthase; FR, Folate Receptor; GART, glycinamide ribonucleotide transformylase; GATOR1, Gap Activity TOward Rags 1; GCL, glutamate cysteine ligase; GCN2, General Control Nonderepressible 2; GCS, glycine cleavage system; GH-Tg, growth hormone transgenic; GlyC, glycine carrier; GMP, guanosine monophosphate; GNMT, glycine-N-methyltransferase; GPI, glycosylphosphatidylinositol; GPX, glutathione peroxidase; GS, GSH synthase; GSH, glutathione; GSSG, glutathione disulfide; $\mathrm{H}_{2} \mathrm{~S}$, hydrogen sulfide; Hcy, homocysteine; IGF, insulin-growth factor; IMM, inner mitochondrial membrane; IMP, inosine monophosphate; ISR, integrated stress response; LCMT-1, leucine carboxyl methyltransferase 1; LRRK2, leucine-rich repeat kinase 2; $\mathrm{m}^{6} \mathrm{~A}$, N6-methyladenosine; MAT, methionine adenosyltransferase; MBD2, Methyl-CpG Binding Domain Protein 2; MFT, mitochondrial folate transporter; MR, methionine restriction; mtDNA, mitochondrial DNA; MTFMT, methionyl-tRNA formyltransferase; MTHFD1, methylene-tetrahydrofolate dehydrogenase 1; MTHFD1L, methylene-tetrahydrofolate dehydrogenase 1 like; MTHFD2, methylenetetrahydrofolate dehydrogenase 2; MTHFD2L, methylene-tetrahydrofolate dehydrogenase 2 like; MTHFR, methylene tetrahydrofolate reductase; mTOR, mechanistic target of rapamycin; MTR, Methionine synthase; MTRR, Methionine Synthase Reductase; NAC, N-Acetyl Cysteine; NADPH, nicotinamide adenine dinucleotide phosphate; OCM, NO, nitric oxide; one-carbon metabolism; PABA, para-aminobenzoic acid; PCFT, Proton-Coupled Folate Transporter; PINK1, phosphatase and tensin homolog-induced putative kinase 1; PP2A, Protein-phosphatase 2A; PSEN1, presenilin 1; RFG, Reduced Folate Carrier; rIIS, reduced insulin/IGF signaling; ROS, reactive oxygen species; RLS, replicative lifespan; SAH, S-adenosylhomocysteine; SAM, S-adenosylmethionine; SAMC, S-Adenosylmethionine Mitochondrial Carrier Protein; SAMTOR, SAM sensor upstream of mTORC1; SARDH, sarcosine dehydrogenase; SFXN1; sideroflexin 1; SHMT1, serine hydroxymethyltransferase 1; SHMT2, serine hydroxymethyltransferase 2; SKN-1, skinhead-1; SLC25A32, Solute Carrier Family 25 Member 32; SN, substantia nigra; SNCA, alpha-synuclein; SUMO, small ubiquitin-like modifier; THF, tetrahydrofolate; TYMS, thymidylate synthase; UPR, unfolded protein response; VPS35, vacuolar protein sorting associated protein 35.

\section{References}

1. Ducker, G.S.; Rabinowitz, J.D. One-carbon metabolism in health and disease. Cell Metab. 2017, 25, 27-42. [CrossRef] [PubMed]

2. Cossins, E.A.; Chen, L. Folates and one-carbon metabolism in plants and fungi. Phytochemistry 1997, 45, 437-452. [CrossRef]

3. Bermingham, A.; Derrick, J.P. The folic acid biosynthesis pathway in bacteria: Evaluation of potential for antibacterial drug discovery. Bioessays 2002, 24, 637-648. [CrossRef]

4. Hanson, A.D.; Gregory, J.F., 3rd. Folate biosynthesis, turnover, and transport in plants. Annu. Rev. Plant. Biol. 2011, 62, 105-125. [CrossRef]

5. Garratt, L.C.; Ortori, C.A.; Tucker, G.A.; Sablitzky, F.; Bennett, M.J.; Barrett, D.A. Comprehensive metabolic profiling of mono- and polyglutamated folates and their precursors in plant and animal tissue using liquid chromatography/negative ion electrospray ionisation tandem mass spectrometry. Rapid Commun. Mass Spectrom. 2005, 19, 2390-2398. [CrossRef]

6. Hou, Z.; Matherly, L.H. Biology of the major facilitative folate transporters slc19a1 and slc46a1. Curr. Top. Membr. 2014, 73, 175-204. [PubMed]

7. Zhao, R.; Diop-Bove, N.; Visentin, M.; Goldman, I.D. Mechanisms of membrane transport of folates into cells and across epithelia. Annu. Rev. Nutr. 2011, 31, 177-201. [CrossRef] [PubMed] 
8. Qiu, A.; Jansen, M.; Sakaris, A.; Min, S.H.; Chattopadhyay, S.; Tsai, E.; Sandoval, C.; Zhao, R.; Akabas, M.H.; Goldman, I.D. Identification of an intestinal folate transporter and the molecular basis for hereditary folate malabsorption. Cell 2006, 127, 917-928. [CrossRef]

9. Matherly, L.H.; Hou, Z.; Gangjee, A. The promise and challenges of exploiting the proton-coupled folate transporter for selective therapeutic targeting of cancer. Cancer Chemother. Pharm. 2018, 81, 1-15. [CrossRef] [PubMed]

10. Matherly, L.H.; Hou, Z. Structure and function of the reduced folate carrier a paradigm of a major facilitator superfamily mammalian nutrient transporter. Vitam. Horm. 2008, 79, 145-184. [PubMed]

11. Alam, C.; Kondo, M.; O'Connor, D.L.; Bendayan, R. Clinical implications of folate transport in the central nervous system. Trends Pharm. Sci. 2020, 41, 349-361. [CrossRef]

12. Ormazabal, A.; Casado, M.; Molero-Luis, M.; Montoya, J.; Rahman, S.; Aylett, S.B.; Hargreaves, I.; Heales, S.; Artuch, R. Can folic acid have a role in mitochondrial disorders? Drug Discov. Today 2015, 20, 1349-1354. [CrossRef]

13. Serrano, M.; Pérez-Dueñas, B.; Montoya, J.; Ormazabal, A.; Artuch, R. Genetic causes of cerebral folate deficiency: Clinical, biochemical and therapeutic aspects. Drug Discov. Today 2012, 17, 1299-1306. [CrossRef]

14. McCord, E.; Pawar, S.; Koneru, T.; Tatiparti, K.; Sau, S.; Iyer, A.K. Folate receptors' expression in gliomas may possess potential nanoparticle-based drug delivery opportunities. ACS Omega 2021, 6, 4111-4118. [CrossRef]

15. Tian, Y.; Wu, G.; Xing, J.C.; Tang, J.; Zhang, Y.; Huang, Z.M.; Jia, Z.C.; Zhao, R.; Tian, Z.Q.; Wang, S.F.; et al. A novel splice variant of folate receptor 4 predominantly expressed in regulatory t cells. BMC Immunol. 2012, 13, 1471-2172. [CrossRef] [PubMed]

16. Tibbetts, A.S.; Appling, D.R. Compartmentalization of mammalian folate-mediated one-carbon metabolism. Annu. Rev. Nutr. 2010, 30, 57-81. [CrossRef] [PubMed]

17. Anderson, D.D.; Quintero, C.M.; Stover, P.J. Identification of a de novo thymidylate biosynthesis pathway in mammalian mitochondria. Proc. Natl. Acad. Sci. USA 2011, 108, 15163-15168. [CrossRef] [PubMed]

18. Chon, J.; Stover, P.J.; Field, M.S. Targeting nuclear thymidylate biosynthesis. Mol. Asp. Med. 2017, 53, 48-56. [CrossRef]

19. Bottiglieri, T. S-adenosyl-1-methionine (same): From the bench to the bedside-molecular basis of a pleiotrophic molecule. Am. J. Clin. Nutr. 2002, 76. [CrossRef]

20. Sanderson, S.M.; Gao, X.; Dai, Z.; Locasale, J.W. Methionine metabolism in health and cancer: A nexus of diet and precision medicine. Nat. Rev. Cancer 2019, 19, 625-637. [CrossRef]

21. Pajares, M.A.; Pérez-Sala, D. Betaine homocysteine s-methyltransferase: Just a regulator of homocysteine metabolism? Cell Mol. Life Sci. 2006, 63, 2792-2803. [CrossRef] [PubMed]

22. Sbodio, J.I.; Snyder, S.H.; Paul, B.D. Regulators of the transsulfuration pathway. Br. J. Pharm. 2019, 176, 583-593. [CrossRef]

23. Kutzbach, C.; Stokstad, E.L. Mammalian methylenetetrahydrofolate reductase. Partial purification, properties, and inhibition by s-adenosylmethionine. Biochim. Biophys. Acta 1971, 250, 459-477. [CrossRef]

24. Finkelstein, J.D. Metabolic regulatory properties of s-adenosylmethionine and s-adenosylhomocysteine. Clin. Chem. Lab. Med. 2007, 45, 1694-1699. [CrossRef] [PubMed]

25. MacFarlane, A.J.; Perry, C.A.; McEntee, M.F.; Lin, D.M.; Stover, P.J. Mthfd1 is a modifier of chemically induced intestinal carcinogenesis. Carcinogenesis 2010, 32, 427-433. [CrossRef] [PubMed]

26. Pietzke, M.; Meiser, J.; Vazquez, A. Formate metabolism in health and disease. Mol. Metab. 2020, 33, 23-37. [CrossRef]

27. Ghannad-Zadeh, K.; Das, S. One-carbon metabolism associated vulnerabilities in glioblastoma: A review. Cancers 2021, $13,3067$. [CrossRef]

28. Krupenko, N.I.; Holmes, R.S.; Tsybovsky, Y.; Krupenko, S.A. Aldehyde dehydrogenase homologous folate enzymes: Evolutionary switch between cytoplasmic and mitochondrial localization. Chem. Biol. Interact. 2015, 234, 12-17. [CrossRef]

29. Anderson, D.D.; Stover, P.J. Shmt1 and shmt2 are functionally redundant in nuclear de novo thymidylate biosynthesis. PLoS ONE 2009, 4, e5839. [CrossRef]

30. Anderson, D.D.; Woeller, C.F.; Chiang, E.-P.; Shane, B.; Stover, P.J. Serine hydroxymethyltransferase anchors de novo thymidylate synthesis pathway to nuclear lamina for DNA synthesis. J. Biol. Chem. 2012, 287, 7051-7062. [CrossRef]

31. Field, M.S.; Kamynina, E.; Agunloye, O.C.; Liebenthal, R.P.; Lamarre, S.G.; Brosnan, M.E.; Brosnan, J.T.; Stover, P.J. Nuclear enrichment of folate cofactors and methylenetetrahydrofolate dehydrogenase 1 ( $\mathrm{mthfd} 1$ ) protect de novo thymidylate biosynthesis during folate deficiency. J. Biol. Chem. 2014, 289, 29642-29650. [CrossRef] [PubMed]

32. Woeller, C.F.; Anderson, D.D.; Szebenyi, D.M.; Stover, P.J. Evidence for small ubiquitin-like modifier-dependent nuclear import of the thymidylate biosynthesis pathway. J. Biol. Chem. 2007, 282, 17623-17631. [CrossRef]

33. Kamynina, E.; Lachenauer, E.R.; DiRisio, A.C.; Liebenthal, R.P.; Field, M.S.; Stover, P.J. Arsenic trioxide targets mthfd1 and sumo-dependent nuclear de novo thymidylate biosynthesis. Proc. Natl. Acad. Sci. USA 2017, 114, E2319-E2326. [CrossRef] [PubMed]

34. Wang, F.K.; Koch, J.; Stokstad, E.L. Folate coenzyme pattern, folate linked enzymes and methionine biosynthesis in rat liver mitochondria. Biochem. Z. 1967, 346, 458-466.

35. Titus, S.A.; Moran, R.G. Retrovirally mediated complementation of the glyb phenotype. Cloning of a human gene encoding the carrier for entry of folates into mitochondria. J. Biol. Chem. 2000, 275, 36811-36817. [CrossRef] [PubMed]

36. Lin, B.F.; Huang, R.F.; Shane, B. Regulation of folate and one-carbon metabolism in mammalian cells. Iii. Role of mitochondrial folylpoly-gamma-glutamate synthetase. J. Biol. Chem. 1993, 268, 21674-21679. [CrossRef] 
37. Kory, N.; Wyant, G.A.; Prakash, G.; Uit de Bos, J.; Bottanelli, F.; Pacold, M.E.; Chan, S.H.; Lewis, C.A.; Wang, T.; Keys, H.R.; et al. Sfxn1 is a mitochondrial serine transporter required for one-carbon metabolism. Science 2018, 362. [CrossRef]

38. Lunetti, P.; Damiano, F.; De Benedetto, G.; Siculella, L.; Pennetta, A.; Muto, L.; Paradies, E.; Marobbio, C.M.T.; Dolce, V.; Capobianco, L. Characterization of human and yeast mitochondrial glycine carriers with implications for heme biosynthesis and anemia*. J. Biol. Chem. 2016, 291, 19746-19759. [CrossRef]

39. Tan, Y.-L.; Sou, N.-L.; Tang, F.-Y.; Ko, H.-A.; Yeh, W.-T.; Peng, J.-H.; Chiang, E.-P.I. Tracing metabolic fate of mitochondrial glycine cleavage system derived formate in vitro and in vivo. Int. J. Mol. Sci. 2020, 21, 8808. [CrossRef]

40. Porter, D.H.; Cook, R.J.; Wagner, C. Enzymatic properties of dimethylglycine dehydrogenase and sarcosine dehydrogenase from rat liver. Arch. BioChem. Biophys. 1985, 243, 396-407. [CrossRef]

41. Zhu, Z.; Leung, G.K.K. More than a metabolic enzyme: Mthfd2 as a novel target for anticancer therapy? Front. Oncol. 2020, 10. [CrossRef] [PubMed]

42. Ben-Sahra, I.; Hoxhaj, G.; Ricoult, S.J.H.; Asara, J.M.; Manning, B.D. Mtorc1 induces purine synthesis through control of the mitochondrial tetrahydrofolate cycle. Science 2016, 351, 728-733. [CrossRef] [PubMed]

43. Yang, L.; Garcia Canaveras, J.C.; Chen, Z.; Wang, L.; Liang, L.; Jang, C.; Mayr, J.A.; Zhang, Z.; Ghergurovich, J.M.; Zhan, L.; et al. Serine catabolism feeds nadh when respiration is impaired. Cell Metab. 2020, 31, 809-821.e806. [CrossRef] [PubMed]

44. Maynard, A.G.; Kanarek, N. Nadh ties one-carbon metabolism to cellular respiration. Cell Metab. 2020, 31, 660-662. [CrossRef] [PubMed]

45. Nicholls, P. Formate as an inhibitor of cytochrome c oxidase. BioChem. Biophys. Res. Commun. 1975, 67, 610-616. [CrossRef]

46. Minton, D.R.; Nam, M.; McLaughlin, D.J.; Shin, J.; Bayraktar, E.C.; Alvarez, S.W.; Sviderskiy, V.O.; Papagiannakopoulos, T.; Sabatini, D.M.; Birsoy, K.; et al. Serine catabolism by shmt2 is required for proper mitochondrial translation initiation and maintenance of formylmethionyl-trnas. Mol. Cell 2018, 69, 610-621. [CrossRef]

47. Esch, B.M.; Limar, S.; Bogdanowski, A.; Gournas, C.; More, T.; Sundag, C.; Walter, S.; Heinisch, J.J.; Ejsing, C.S.; André, B.; et al. Uptake of exogenous serine is important to maintain sphingolipid homeostasis in saccharomyces cerevisiae. PLOS Genet. 2020, 16, e1008745. [CrossRef]

48. Horne, D.W.; Holloway, R.S.; Wagner, C. Transport of s-adenosylmethionine in isolated rat liver mitochondria. Arch. BioChem. Biophys. 1997, 343, 201-206. [CrossRef]

49. Agrimi, G.; Di Noia, M.A.; Marobbio, C.M.; Fiermonte, G.; Lasorsa, F.M.; Palmieri, F. Identification of the human mitochondrial s-adenosylmethionine transporter: Bacterial expression, reconstitution, functional characterization and tissue distribution. BioChem. J. 2004, 379, 183-190. [CrossRef]

50. Schober, F.A.; Moore, D.; Atanassov, I.; Moedas, M.F.; Clemente, P.; Végvári, Á.; Fissi, N.E.; Filograna, R.; Bucher, A.L.; Hinze, Y.; et al. The one-carbon pool controls mitochondrial energy metabolism via complex i and iron-sulfur clusters. Sci. Adv. 2021, 7. [CrossRef]

51. Zheng, Y.; Lin, T.Y.; Lee, G.; Paddock, M.N.; Momb, J.; Cheng, Z.; Li, Q.; Fei, D.L.; Stein, B.D.; Ramsamooj, S.; et al. Mitochondrial one-carbon pathway supports cytosolic folate integrity in cancer cells. Cell 2018, 175, 1546-1560. [CrossRef]

52. De Vitto, H.; Arachchige, D.B.; Richardson, B.C.; French, J.B. The intersection of purine and mitochondrial metabolism in cancer. Cells 2021, 10, 2603. [CrossRef] [PubMed]

53. French, J.B.; Jones, S.A.; Deng, H.; Pedley, A.M.; Kim, D.; Chan, C.Y.; Hu, H.; Pugh, R.J.; Zhao, H.; Zhang, Y.; et al. Spatial colocalization and functional link of purinosomes with mitochondria. Science 2016, 351, 733-737. [CrossRef] [PubMed]

54. Plummer, J.D.; Johnson, J.E. Extension of cellular lifespan by methionine restriction involves alterations in central carbon metabolism and is mitophagy-dependent. Front. Cell Dev. Biol. 2019, 7. [CrossRef] [PubMed]

55. Fabrizio, P.; Longo, V.D. The chronological life span of saccharomyces cerevisiae. Methods Mol. Biol. 2007, 371, 89-95. [PubMed]

56. Ruckenstuhl, C.; Netzberger, C.; Entfellner, I.; Carmona-Gutierrez, D.; Kickenweiz, T.; Stekovic, S.; Gleixner, C.; Schmid, C.; Klug, L.; Sorgo, A.G.; et al. Lifespan extension by methionine restriction requires autophagy-dependent vacuolar acidification. PLoS Genet. 2014, 10. [CrossRef]

57. Johnson, J.E.; Johnson, F.B. Methionine restriction activates the retrograde response and confers both stress tolerance and lifespan extension to yeast, mouse and human cells. PLOS ONE 2014, 9. [CrossRef]

58. McCormick, M.A.; Delaney, J.R.; Tsuchiya, M.; Tsuchiyama, S.; Shemorry, A.; Sim, S.; Chou, A.C.; Ahmed, U.; Carr, D.; Murakami, C.J.; et al. A comprehensive analysis of replicative lifespan in 4,698 single-gene deletion strains uncovers conserved mechanisms of aging. Cell Metab. 2015, 22, 895-906. [CrossRef]

59. Laschober, G.T.; Ruli, D.; Hofer, E.; Muck, C.; Carmona-Gutierrez, D.; Ring, J.; Hutter, E.; Ruckenstuhl, C.; Micutkova, L.; Brunauer, R.; et al. Identification of evolutionarily conserved genetic regulators of cellular aging. Aging Cell 2010, 9, $1084-1097$. [CrossRef] [PubMed]

60. Hine, C.; Harputlugil, E.; Zhang, Y.; Ruckenstuhl, C.; Lee, B.C.; Brace, L.; Longchamp, A.; Treviño-Villarreal, J.H.; Mejia, P.; Ozaki, C.K.; et al. Endogenous hydrogen sulfide production is essential for dietary restriction benefits. Cell 2015, 160, 132-144. [CrossRef]

61. Tello-Padilla, M.F.; Perez-Gonzalez, A.Y.; Canizal-García, M.; González-Hernández, J.C.; Cortes-Rojo, C.; Olivares-Marin, I.K.; Madrigal-Perez, L.A. Glutathione levels influence chronological life span of saccharomyces cerevisiae in a glucose-dependent manner. Yeast 2018, 35, 387-396. [CrossRef] 
62. Virk, B.; Correia, G.; Dixon, D.P.; Feyst, I.; Jia, J.; Oberleitner, N.; Briggs, Z.; Hodge, E.; Edwards, R.; Ward, J.; et al. Excessive folate synthesis limits lifespan in the c. Elegans: E. Coli aging model. BMC Biol. 2012, 10, 1741-7007. [CrossRef] [PubMed]

63. Annibal, A.; Tharyan, R.G.; Schonewolff, M.F.; Tam, H.; Latza, C.; Auler, M.M.K.; Grönke, S.; Partridge, L.; Antebi, A. Regulation of the one carbon folate cycle as a shared metabolic signature of longevity. Nat. Commun. 2021, 12, 021-23856. [CrossRef] [PubMed]

64. Anderson, E.N.; Corkins, M.E.; Li, J.C.; Singh, K.; Parsons, S.; Tucey, T.M.; Sorkaç, A.; Huang, H.; Dimitriadi, M.; Sinclair, D.A.; et al. C. Elegans lifespan extension by osmotic stress requires fudr, base excision repair, foxo, and sirtuins. Mech. Ageing Dev. 2016, 154, 30-42. [CrossRef]

65. Liu, Y.J.; Janssens, G.E.; McIntyre, R.L.; Molenaars, M.; Kamble, R.; Gao, A.W.; Jongejan, A.; Weeghel, M.V.; MacInnes, A.W.; Houtkooper, R.H. Glycine promotes longevity in caenorhabditis elegans in a methionine cycle-dependent fashion. PLoS Genet. 2019, 15. [CrossRef]

66. Hansen, M.; Hsu, A.L.; Dillin, A.; Kenyon, C. New genes tied to endocrine, metabolic, and dietary regulation of lifespan from a caenorhabditis elegans genomic rnai screen. PLoS Genet. 2005, 1, 119-128. [CrossRef] [PubMed]

67. Chen, C.C.; Lim, C.Y.; Lee, P.J.; Hsu, A.L.; Ching, T.T. S-adenosyl methionine synthetase sams-5 mediates dietary restrictioninduced longevity in caenorhabditis elegans. PLOS ONE 2020, 15. [CrossRef]

68. Edwards, C.; Canfield, J.; Copes, N.; Brito, A.; Rehan, M.; Lipps, D.; Brunquell, J.; Westerheide, S.D.; Bradshaw, P.C. Mechanisms of amino acid-mediated lifespan extension in caenorhabditis elegans. BMC Genet. 2015, 16, 015-0167. [CrossRef]

69. Cabreiro, F.; Au, C.; Leung, K.Y.; Vergara-Irigaray, N.; Cochemé, H.M.; Noori, T.; Weinkove, D.; Schuster, E.; Greene, N.D.; Gems, D. Metformin retards aging in c. Elegans by altering microbial folate and methionine metabolism. Cell 2013, 153, 228-239. [CrossRef]

70. Miller, D.L.; Roth, M.B. Hydrogen sulfide increases thermotolerance and lifespan in caenorhabditis elegans. Proc. Natl. Acad. Sci. USA 2007, 104, 20618-20622. [CrossRef]

71. Ng, L.T.; Ng, L.F.; Tang, R.M.Y.; Barardo, D.; Halliwell, B.; Moore, P.K.; Gruber, J. Lifespan and healthspan benefits of exogenous h2s in c. Elegans are independent from effects downstream of eat-2 mutation. NPJ Aging Mech. Dis. 2020, 6, 6. [CrossRef] [PubMed]

72. Oh, S.I.; Park, J.K.; Park, S.K. Lifespan extension and increased resistance to environmental stressors by n-acetyl-1-cysteine in caenorhabditis elegans. Clinics 2015, 70, 380-386. [CrossRef]

73. Gusarov, I.; Shamovsky, I.; Pani, B.; Gautier, L.; Eremina, S.; Katkova-Zhukotskaya, O.; Mironov, A.; Makarov, A.; Nudler, E. Dietary thiols accelerate aging of c. Elegans. Nat. Commun. 2021, 12, 021-24634. [CrossRef] [PubMed]

74. Obata, F.; Miura, M. Enhancing s-adenosyl-methionine catabolism extends drosophila lifespan. Nat. Commun. 2015, 6, 8332. [CrossRef] [PubMed]

75. Troen, A.M.; French, E.E.; Roberts, J.F.; Selhub, J.; Ordovas, J.M.; Parnell, L.D.; Lai, C.Q. Lifespan modification by glucose and methionine in drosophila melanogaster fed a chemically defined diet. Age 2007, 29, 29-39. [CrossRef]

76. Lee, B.C.; Kaya, A.; Ma, S.; Kim, G.; Gerashchenko, M.V.; Yim, S.H.; Hu, Z.; Harshman, L.G.; Gladyshev, V.N. Methionine restriction extends lifespan of drosophila melanogaster under conditions of low amino-acid status. Nat. Commun. 2014, 5, 3592. [CrossRef]

77. Kabil, H.; Kabil, O.; Banerjee, R.; Harshman, L.G.; Pletcher, S.D. Increased transsulfuration mediates longevity and dietary restriction in drosophila. Proc. Natl. Acad. Sci. USA 2011, 108, 16831-16836. [CrossRef]

78. Shaposhnikov, M.; Proshkina, E.; Koval, L.; Zemskaya, N.; Zhavoronkov, A.; Moskalev, A. Overexpression of cbs and cse genes affects lifespan, stress resistance and locomotor activity in drosophila melanogaster. Aging 2018, 10, 3260-3272. [CrossRef]

79. Orr, W.C.; Radyuk, S.N.; Prabhudesai, L.; Toroser, D.; Benes, J.J.; Luchak, J.M.; Mockett, R.J.; Rebrin, I.; Hubbard, J.G.; Sohal, R.S. Overexpression of glutamate-cysteine ligase extends life span in drosophila melanogaster. J. Biol. Chem. 2005, 280, 37331-37338. [CrossRef]

80. Parkhitko, A.A.; Binari, R.; Zhang, N.; Asara, J.M.; Demontis, F.; Perrimon, N. Tissue-specific down-regulation of s-adenosylhomocysteine via suppression of dahcyl1/dahcyl2 extends health span and life span in drosophila. Genes Dev. 2016, 30, 1409-1422. [CrossRef]

81. Lemon, J.A.; Boreham, D.R.; Rollo, C.D. A complex dietary supplement extends longevity of mice. J. Gerontol. A Biol. Sci. Med. Sci. 2005, 60, 275-279. [CrossRef]

82. Anisimov, V.N.; Berstein, L.M.; Popovich, I.G.; Zabezhinski, M.A.; Egormin, P.A.; Piskunova, T.S.; Semenchenko, A.V.; Tyndyk, M.L.; Yurova, M.N.; Kovalenko, I.G.; et al. If started early in life, metformin treatment increases life span and postpones tumors in female shr mice. Aging 2011, 3, 148-157. [CrossRef] [PubMed]

83. Miller, R.A.; Buehner, G.; Chang, Y.; Harper, J.M.; Sigler, R.; Smith-Wheelock, M. Methionine-deficient diet extends mouse lifespan, slows immune and lens aging, alters glucose, $t 4$, igf-i and insulin levels, and increases hepatocyte mif levels and stress resistance. Aging Cell 2005, 4, 119-125. [CrossRef] [PubMed]

84. Orentreich, N.; Matias, J.R.; DeFelice, A.; Zimmerman, J.A. Low methionine ingestion by rats extends life span. J. Nutr. 1993, 123, 269-274. [PubMed]

85. Richie, J.P., Jr.; Leutzinger, Y.; Parthasarathy, S.; Malloy, V.; Orentreich, N.; Zimmerman, J.A. Methionine restriction increases blood glutathione and longevity in $\mathrm{f} 344$ rats. FASEB J. 1994, 8, 1302-1307. [CrossRef] 
86. Ito, T.; Yoshikawa, N.; Inui, T.; Miyazaki, N.; Schaffer, S.W.; Azuma, J. Tissue depletion of taurine accelerates skeletal muscle senescence and leads to early death in mice. PLOS ONE 2014, 9, e107409. [CrossRef]

87. Husemoen, L.L.; Skaaby, T.; Jørgensen, T.; Thuesen, B.H.; Fenger, M.; Grarup, N.; Sandholt, C.H.; Hansen, T.; Pedersen, O.; Linneberg, A. Mthfr c677t genotype and cardiovascular risk in a general population without mandatory folic acid fortification. Eur. J. Nutr. 2014, 53, 1549-1559. [CrossRef]

88. Yang, Q.; Bailey, L.; Clarke, R.; Flanders, W.D.; Liu, T.; Yesupriya, A.; Khoury, M.J.; Friedman, J.M. Prospective study of methylenetetrahydrofolate reductase (mthfr) variant $\mathrm{c} 677 \mathrm{t}$ and risk of all-cause and cardiovascular disease mortality among 6000 us adults. Am. J. Clin. Nutr. 2012, 95, 1245-1253. [CrossRef]

89. Varela-Moreiras, G.; Pérez-Olleros, L.; García-Cuevas, M.; Ruiz-Roso, B. Effects of ageing on folate metabolism in rats fed a long-term folate deficient diet. Int. J. Vitam. Nutr. Res. 1994, 64, 294-299.

90. Challet, E.; Dumont, S.; Mehdi, M.K.; Allemann, C.; Bousser, T.; Gourmelen, S.; Sage-Ciocca, D.; Hicks, D.; Pévet, P.; Claustrat, B. Aging-like circadian disturbances in folate-deficient mice. NeuroBiol. Aging 2013, 34, 1589-1598. [CrossRef]

91. Bahous, R.H.; Cosín-Tomás, M.; Deng, L.; Leclerc, D.; Malysheva, O.; Ho, M.K.; Pallàs, M.; Kaliman, P.; Bedell, B.J.; Caudill, M.A.; et al. Early manifestations of brain aging in mice due to low dietary folate and mild mthfr deficiency. Mol. NeuroBiol. 2019, 56, 4175-4191. [CrossRef]

92. Ukraintseva, S.; Yashin, A.; Arbeev, K.; Kulminski, A.; Akushevich, I.; Wu, D.; Joshi, G.; Land, K.C.; Stallard, E. Puzzling role of genetic risk factors in human longevity: "Risk alleles" as pro-longevity variants. Biogerontology 2016, 17, 109-127. [CrossRef]

93. Hall, H.; Cooper, B.R.; Qi, G.; Wijeratne, A.B.; Mosley, A.L.; Weake, V.M. Quantitative proteomic and metabolomic profiling reveals altered mitochondrial metabolism and folate biosynthesis pathways in the aging drosophila eye. Mol. Cell Proteom. 2021, 20, 100127. [CrossRef] [PubMed]

94. Virk, B.; Jia, J.; Maynard, C.A.; Raimundo, A.; Lefebvre, J.; Richards, S.A.; Chetina, N.; Liang, Y.; Helliwell, N.; Cipinska, M.; et al. Folate acts in e. coli to accelerate c. elegans aging independently of bacterial biosynthesis. Cell Rep. 2016, 14, 1611-1620. [CrossRef] [PubMed]

95. Onken, B.; Driscoll, M. Metformin induces a dietary restriction-like state and the oxidative stress response to extend c. Elegans healthspan via ampk, lkb1, and skn-1. PLoS ONE 2010, 5, 0008758. [CrossRef] [PubMed]

96. Blount, B.C.; Mack, M.M.; Wehr, C.M.; MacGregor, J.T.; Hiatt, R.A.; Wang, G.; Wickramasinghe, S.N.; Everson, R.B.; Ames, B.N. Folate deficiency causes uracil misincorporation into human DNA and chromosome breakage: Implications for cancer and neuronal damage. Proc. Natl. Acad. Sci. USA 1997, 94, 3290-3295. [CrossRef]

97. Chow, H.M.; Herrup, K. Genomic integrity and the ageing brain. Nat. Rev. NeuroSci. 2015, 16, 672-684. [CrossRef]

98. Steinberg, S.E.; Fonda, S.; Campbell, C.L.; Hillman, R.S. Cellular abnormalities of folate deficiency. Br. J. Haematol. 1983, 54, 605-612. [CrossRef]

99. Kesavan, V.; Pote, M.S.; Batra, V.; Viswanathan, G. Increased folate catabolism following total body gamma-irradiation in mice. J. Radiat. Res. 2003, 44, 141-144. [CrossRef]

100. Batra, V.; Kesavan, V.; Mishra, K.P. Modulation of enzymes involved in folate dependent one-carbon metabolism by gammaradiation stress in mice. J. Radiat. Res. 2004, 45, 527-533. [CrossRef]

101. Choi, S.W.; Kim, Y.I.; Weitzel, J.N.; Mason, J.B. Folate depletion impairs DNA excision repair in the colon of the rat. Gut 1998, 43 , 93-99. [CrossRef] [PubMed]

102. Simon, K.W.; Ma, H.; Dombkowski, A.A.; Cabelof, D.C. Aging alters folate homeostasis and DNA damage response in colon. Mech. Ageing Dev. 2012, 133, 75-82. [CrossRef]

103. Dorling, J.L.; Martin, C.K.; Redman, L.M. Calorie restriction for enhanced longevity: The role of novel dietary strategies in the present obesogenic environment. Ageing Res. Rev. 2020, 64, 25. [CrossRef] [PubMed]

104. Lee, B.C.; Kaya, A.; Gladyshev, V.N. Methionine restriction and life-span control. Ann. NY Acad. Sci. 2016, 10. [CrossRef] [PubMed]

105. Parkhitko, A.A.; Jouandin, P.; Mohr, S.E.; Perrimon, N. Methionine metabolism and methyltransferases in the regulation of aging and lifespan extension across species. Aging Cell 2019, 18, 28. [CrossRef]

106. Mota-Martorell, N.; Jové, M.; Berdún, R.; Pamplona, R. Plasma methionine metabolic profile is associated with longevity in mammals. Commun. Biol. 2021, 4, 725. [CrossRef]

107. Sanz, A.; Caro, P.; Ayala, V.; Portero-Otin, M.; Pamplona, R.; Barja, G. Methionine restriction decreases mitochondrial oxygen radical generation and leak as well as oxidative damage to mitochondrial DNA and proteins. FASEB J. 2006, 20, 1064-1073. [CrossRef] [PubMed]

108. Lees, E.K.; Król, E.; Grant, L.; Shearer, K.; Wyse, C.; Moncur, E.; Bykowska, A.S.; Mody, N.; Gettys, T.W.; Delibegovic, M. Methionine restriction restores a younger metabolic phenotype in adult mice with alterations in fibroblast growth factor 21. Aging Cell 2014, 13, 817-827. [CrossRef]

109. Stone, K.P.; Wanders, D.; Orgeron, M.; Cortez, C.C.; Gettys, T.W. Mechanisms of increased in vivo insulin sensitivity by dietary methionine restriction in mice. Diabetes 2014, 63, 3721-3733. [CrossRef]

110. Wanders, D.; Forney, L.A.; Stone, K.P.; Burk, D.H.; Pierse, A.; Gettys, T.W. Fgf21 mediates the thermogenic and insulin-sensitizing effects of dietary methionine restriction but not its effects on hepatic lipid metabolism. Diabetes 2017, 66, 858-867. [CrossRef] 
111. Wanders, D.; Stone, K.P.; Forney, L.A.; Cortez, C.C.; Dille, K.N.; Simon, J.; Xu, M.; Hotard, E.C.; Nikonorova, I.A.; Pettit, A.P.; et al. Role of gcn2-independent signaling through a noncanonical perk/nrf2 pathway in the physiological responses to dietary methionine restriction. Diabetes 2016, 65, 1499-1510. [CrossRef] [PubMed]

112. Gu, X.; Orozco, J.M.; Saxton, R.A.; Condon, K.J.; Liu, G.Y.; Krawczyk, P.A.; Scaria, S.M.; Harper, J.W.; Gygi, S.P.; Sabatini, D.M. Samtor is an s-adenosylmethionine sensor for the mtorc1 pathway. Science 2017, 358, 813-818. [CrossRef]

113. Stone, K.P.; Ghosh, S.; Kovalik, J.P.; Orgeron, M.; Wanders, D.; Sims, L.C.; Gettys, T.W. The acute transcriptional responses to dietary methionine restriction are triggered by inhibition of ternary complex formation and linked to erk $1 / 2$, mtor, and atf 4 Sci. Rep. 2021, 11, 021-83380. [CrossRef]

114. Aissa, A.F.; Gomes, T.D.; Almeida, M.R.; Hernandes, L.C.; Darin, J.D.; Bianchi, M.L.; Antunes, L.M. Methionine concentration in the diet has a tissue-specific effect on chromosomal stability in female mice. Food Chem. Toxicol. 2013, 62, 456-462. [CrossRef] [PubMed]

115. Bárcena, C.; López-Otín, C.; Kroemer, G. Methionine restriction for improving progeria: Another autophagy-inducing anti-aging strategy? Autophagy 2019, 15, 558-559. [CrossRef] [PubMed]

116. Zou, K.; Rouskin, S.; Dervishi, K.; McCormick, M.A.; Sasikumar, A.; Deng, C.; Chen, Z.; Kaeberlein, M.; Brem, R.B.; Polymenis, M.; et al. Life span extension by glucose restriction is abrogated by methionine supplementation: Cross-talk between glucose and methionine and implication of methionine as a key regulator of life span. Sci. Adv. 2020, 6. [CrossRef] [PubMed]

117. Tain, L.S.; Jain, C.; Nespital, T.; Froehlich, J.; Hinze, Y.; Grönke, S.; Partridge, L. Longevity in response to lowered insulin signaling requires glycine n-methyltransferase-dependent spermidine production. Aging Cell 2020, 19, e13043. [CrossRef] [PubMed]

118. Brown-Borg, H.M.; Rakoczy, S.; Wonderlich, J.A.; Borg, K.E.; Rojanathammanee, L. Metabolic adaptation of short-living growth hormone transgenic mice to methionine restriction and supplementation. Ann. NY Acad. Sci. 2018, 1418, 118-136. [CrossRef] [PubMed]

119. Jang, H.S.; Shin, W.J.; Lee, J.E.; Do, J.T. Cpg and non-cpg methylation in epigenetic gene regulation and brain function. Genes 2017, 8, 148. [CrossRef] [PubMed]

120. Greenberg, M.V.C.; Bourc'his, D. The diverse roles of DNA methylation in mammalian development and disease. Nat. Rev. Mol. Cell Biol. 2019, 20, 590-607. [CrossRef] [PubMed]

121. Bollati, V.; Schwartz, J.; Wright, R.; Litonjua, A.; Tarantini, L.; Suh, H.; Sparrow, D.; Vokonas, P.; Baccarelli, A. Decline in genomic DNA methylation through aging in a cohort of elderly subjects. Mech. Ageing Dev. 2009, 130, 234-239. [CrossRef] [PubMed]

122. Horvath, S.; Zhang, Y.; Langfelder, P.; Kahn, R.S.; Boks, M.P.M.; van Eijk, K.; van den Berg, L.H.; Ophoff, R.A. Aging effects on DNA methylation modules in human brain and blood tissue. Genome Biol. 2012, 13, R97. [CrossRef] [PubMed]

123. Horvath, S.; Gurven, M.; Levine, M.E.; Trumble, B.C.; Kaplan, H.; Allayee, H.; Ritz, B.R.; Chen, B.; Lu, A.T.; Rickabaugh, T.M.; et al An epigenetic clock analysis of race/ethnicity, sex, and coronary heart disease. Genome Biol. 2016, 17, 171. [CrossRef] [PubMed]

124. Singhal, R.P.; Mays-Hoopes, L.L.; Eichhorn, G.L. DNA methylation in aging of mice. Mech. Ageing Dev. 1987, 41, 199-210. [CrossRef]

125. Vanyushin, B.F.; Nemirovsky, L.E.; Klimenko, V.V.; Vasiliev, V.K.; Belozersky, A.N. The 5-methylcytosine in DNA of rats. Tissue and age specificity and the changes induced by hydrocortisone and other agents. Gerontologia 1973, 19, 138-152. [CrossRef]

126. Cole, J.J.; Robertson, N.A.; Rather, M.I.; Thomson, J.P.; McBryan, T.; Sproul, D.; Wang, T.; Brock, C.; Clark, W.; Ideker, T.; et al Diverse interventions that extend mouse lifespan suppress shared age-associated epigenetic changes at critical gene regulatory regions. Genome Biol. 2017, 18, 58. [CrossRef]

127. Wilkinson, G.S.; Adams, D.M.; Haghani, A.; Lu, A.T.; Zoller, J.; Breeze, C.E.; Arnold, B.D.; Ball, H.C.; Carter, G.G.; Cooper, L.N.; et al. DNA methylation predicts age and provides insight into exceptional longevity of bats. Nat. Commun. 2021, 12, 1615. [CrossRef]

128. Lozoya, O.A.; Martinez-Reyes, I.; Wang, T.; Grenet, D.; Bushel, P.; Li, J.; Chandel, N.; Woychik, R.P.; Santos, J.H. Mitochondrial nicotinamide adenine dinucleotide reduced (nadh) oxidation links the tricarboxylic acid (tca) cycle with methionine metabolism and nuclear DNA methylation. PLoS Biol. 2018, 16. [CrossRef]

129. Han, S.; Brunet, A. Histone methylation makes its mark on longevity. Trends Cell Biol. 2012, 22, 42-49. [CrossRef]

130. Kumar, A.; Palfrey, H.A.; Pathak, R.; Kadowitz, P.J.; Gettys, T.W.; Murthy, S.N. The metabolism and significance of homocysteine in nutrition and health. Nutr. Metab. 2017, 14, 017-0233. [CrossRef]

131. Ostrakhovitch, E.A.; Tabibzadeh, S. Homocysteine and age-associated disorders. Ageing Res. Rev. 2019, 49, 144-164. [CrossRef] [PubMed]

132. Perna, A.F.; Ingrosso, D. Homocysteine and Chronic Kidney Disease: An Ongoing Narrative. J Nephrol. 2019, 32, 673-675. [CrossRef] [PubMed]

133. van Ede, A.E.; Laan, R.F.; Blom, H.J.; Boers, G.H.; Haagsma, C.J.; Thomas, C.M.; De Boo, T.M.; van de Putte, L.B. Homocysteine and folate status in methotrexate-treated patients with rheumatoid arthritis. Rheumatology 2002, 41, 658-665. [CrossRef]

134. Schwaninger, M.; Ringleb, P.; Winter, R.; Kohl, B.; Fiehn, W.; Rieser, P.A.; Walter-Sack, I. Elevated plasma concentrations of homocysteine in antiepileptic drug treatment. Epilepsia 1999, 40, 345-350. [CrossRef] [PubMed]

135. Konstantinova, S.V.; Tell, G.S.; Vollset, S.E.; Nygård, O.; Bleie, Ø.; Ueland, P.M. Divergent associations of plasma choline and betaine with components of metabolic syndrome in middle age and elderly men and women. J. Nutr. 2008, 138, 914-920. [CrossRef] [PubMed] 
136. Huang, B.X.; Zhu, Y.Y.; Tan, X.Y.; Lan, Q.Y.; Li, C.L.; Chen, Y.M.; Zhu, H.L. Serum betaine is inversely associated with low lean mass mainly in men in a chinese middle-aged and elderly community-dwelling population. Br. J. Nutr. 2016, 115, 2181-2188. [CrossRef] [PubMed]

137. Lee, H.J.; Noormohammadi, A.; Koyuncu, S.; Calculli, G.; Simic, M.S.; Herholz, M.; Trifunovic, A.; Vilchez, D. Prostaglandin signals from adult germ stem cells delay somatic aging of caenorhabditis elegans. Nat. Metab. 2019, 1, 790-810. [CrossRef] [PubMed]

138. Mota-Martorell, N.; Jové, M.; Borrás, C.; Berdún, R.; Obis, È.; Sol, J.; Cabré, R.; Pradas, I.; Galo-Licona, J.D.; Puig, J.; et al Methionine transsulfuration pathway is upregulated in long-lived humans. Free Radic. Biol. Med. 2021, 162, 38-52. [CrossRef]

139. Sokolov, A.S.; Nekrasov, P.V.; Shaposhnikov, M.V.; Moskalev, A.A. Hydrogen sulfide in longevity and pathologies: Inconsistency is malodorous. Ageing Res. Rev. 2021, 67, 28. [CrossRef] [PubMed]

140. Zhang, Y.; Tang, Z.H.; Ren, Z.; Qu, S.L.; Liu, M.H.; Liu, L.S.; Jiang, Z.S. Hydrogen sulfide, the next potent preventive and therapeutic agent in aging and age-associated diseases. Mol. Cell Biol. 2013, 33, 1104-1113. [CrossRef]

141. Dziegelewska, M.; Holtze, S.; Vole, C.; Wachter, U.; Menzel, U.; Morhart, M.; Groth, M.; Szafranski, K.; Sahm, A.; Sponholz, C.; et al. Low sulfide levels and a high degree of cystathionine $\beta$-synthase (cbs) activation by s-adenosylmethionine (sam) in the long-lived naked mole-rat. Redox Biol. 2016, 8, 192-198. [CrossRef] [PubMed]

142. Wei, Y.; Kenyon, C. Roles for ros and hydrogen sulfide in the longevity response to germline loss in caenorhabditis elegans. Proc. Natl. Acad. Sci. USA 2016, 113, E2832-E2841. [CrossRef] [PubMed]

143. Bithi, N.; Link, C.; Henderson, Y.O.; Kim, S.; Yang, J.; Li, L.; Wang, R.; Willard, B.; Hine, C. Dietary restriction transforms the mammalian protein persulfidome in a tissue-specific and cystathionine $\gamma$-lyase-dependent manner. Nat. Commun. 2021, 12, 1-20. [CrossRef] [PubMed]

144. Pow, D.V.; Sullivan, R.; Reye, P.; Hermanussen, S. Localization of taurine transporters, taurine, and (3)h taurine accumulation in the rat retina, pituitary, and brain. Glia 2002, 37, 153-168. [CrossRef] [PubMed]

145. Ames, B.N. Prolonging healthy aging: Longevity vitamins and proteins. Proc. Natl. Acad. Sci. USA 2018, 115, 10836-10844. [CrossRef] [PubMed]

146. Du, G.; Liu, Z.; Yu, Z.; Zhuo, Z.; Zhu, Y.; Zhou, J.; Li, Y.; Chen, H. Taurine represses age-associated gut hyperplasia in drosophila via counteracting endoplasmic reticulum stress. Aging Cell 2021, 20, e13319. [CrossRef]

147. Liu, Y.; Hyde, A.S.; Simpson, M.A.; Barycki, J.J. Emerging regulatory paradigms in glutathione metabolism. Adv. Cancer Res. 2014, 122, 69-101. [PubMed]

148. Go, Y.M.; Jones, D.P. Redox theory of aging: Implications for health and disease. Clin. Sci. 2017, 131, 1669-1688. [CrossRef]

149. Schulz, T.J.; Zarse, K.; Voigt, A.; Urban, N.; Birringer, M.; Ristow, M. Glucose restriction extends caenorhabditis elegans life span by inducing mitochondrial respiration and increasing oxidative stress. Cell Metab. 2007, 6, 280-293. [CrossRef]

150. Elshorbagy, A.K.; Jernerén, F.; Scudamore, C.L.; McMurray, F.; Cater, H.; Hough, T.; Cox, R.; Refsum, H. Exploring the lean phenotype of glutathione-depleted mice: Thiol, amino acid and fatty acid profiles. PLoS ONE 2016, 11. [CrossRef]

151. Kumar, P.; Liu, C.; Hsu, J.W.; Chacko, S.; Minard, C.; Jahoor, F.; Sekhar, R.V. Glycine and n-acetylcysteine (glynac) supplementation in older adults improves glutathione deficiency, oxidative stress, mitochondrial dysfunction, inflammation, insulin resistance, endothelial dysfunction, genotoxicity, muscle strength, and cognition: Results of a pilot clinical trial. Clin. Transl. Med. 2021, $11,372$.

152. El-Hafidi, M.; Franco, M.; Ramírez, A.R.; Sosa, J.S.; Flores, J.A.P.; Acosta, O.L.; Salgado, M.C.; Cardoso-Saldaña, G. Glycine increases insulin sensitivity and glutathione biosynthesis and protects against oxidative stress in a model of sucrose-induced insulin resistance. Oxid. Med. Cell Longev. 2018, 21. [CrossRef] [PubMed]

153. Sekhar, R.V.; McKay, S.V.; Patel, S.G.; Guthikonda, A.P.; Reddy, V.T.; Balasubramanyam, A.; Jahoor, F. Glutathione synthesis is diminished in patients with uncontrolled diabetes and restored by dietary supplementation with cysteine and glycine. Diabetes Care 2011, 34, 162-167. [CrossRef] [PubMed]

154. Dekhne, A.S.; Hou, Z.; Gangjee, A.; Matherly, L.H. Therapeutic targeting of mitochondrial one-carbon metabolism in cancer. Mol. Cancer Ther. 2020, 19, 2245-2255. [CrossRef] [PubMed]

155. Korsmo, H.W.; Jiang, X. One carbon metabolism and early development: A diet-dependent destiny. Trends Endocrinol. Metab. 2021, 32, 579-593. [CrossRef]

156. Reina-Campos, M.; Diaz-Meco, M.T.; Moscat, J. The complexity of the serine glycine one-carbon pathway in cancer. J. Cell Biol. 2019, 219. [CrossRef] [PubMed]

157. Yang, M.; Vousden, K.H. Serine and one-carbon metabolism in cancer. Nat. Rev. Cancer 2016, 16, 650-662. [CrossRef] [PubMed]

158. Imbard, A.; Benoist, J.-F.; Blom, H.J. Neural tube defects, folic acid and methylation. Int. J. Environ. Res. Public Health 2013, 10, 4352-4389. [CrossRef] [PubMed]

159. Naninck, E.F.G.; Stijger, P.C.; Brouwer-Brolsma, E.M. The importance of maternal folate status for brain development and function of offspring. Adv. Nutr. 2019, 10, 502-519. [CrossRef]

160. Troen, A.M. Folate and vitamin b12: Function and importance in cognitive development. Nestle Nutr. Inst. Workshop Ser. 2012, 70, $161-171$.

161. Kronenberg, G.; Colla, M.; Endres, M. Folic acid, neurodegenerative and neuropsychiatric disease. Curr. Mol. Med. 2009, 9, 315-323. [CrossRef] [PubMed] 
162. Coppedè, F. One-carbon epigenetics and redox biology of neurodegeneration. Free Radic. Biol. Med. 2021, 170, 19-33. [CrossRef] [PubMed]

163. Knopman, D.S.; Amieva, H.; Petersen, R.C.; Chételat, G.; Holtzman, D.M.; Hyman, B.T.; Nixon, R.A.; Jones, D.T. Alzheimer disease. Nat. Rev. Dis. Primers 2021, 7, 33. [CrossRef] [PubMed]

164. Otaegui-Arrazola, A.; Amiano, P.; Elbusto, A.; Urdaneta, E.; Martínez-Lage, P. Diet, cognition, and alzheimer's disease: Food for thought. Eur. J. Nutr. 2014, 53, 1-23. [CrossRef] [PubMed]

165. Corrada, M.M.; Kawas, C.H.; Hallfrisch, J.; Muller, D.; Brookmeyer, R. Reduced risk of alzheimer's disease with high folate intake: The baltimore longitudinal study of aging. Alzheimers Dement. 2005, 1, 11-18. [CrossRef]

166. Luchsinger, J.A.; Tang, M.-X.; Miller, J.; Green, R.; Mayeux, R. Relation of higher folate intake to lower risk of alzheimer disease in the elderly. Arch. Neurol. 2007, 64, 86-92. [CrossRef] [PubMed]

167. Ma, F.; Wu, T.; Zhao, J.; Song, A.; Liu, H.; Xu, W.; Huang, G. Folic acid supplementation improves cognitive function by reducing the levels of peripheral inflammatory cytokines in elderly chinese subjects with mci. Sci. Rep. 2016, 6, 37486. [CrossRef]

168. Sofi, F.; Cesari, F.; Abbate, R.; Gensini, G.F.; Casini, A. Adherence to mediterranean diet and health status: Meta-analysis. BMJ 2008, 337, a1344. [CrossRef]

169. Ravaglia, G.; Forti, P.; Maioli, F.; Martelli, M.; Servadei, L.; Brunetti, N.; Porcellini, E.; Licastro, F. Homocysteine and folate as risk factors for dementia and alzheimer disease. Am. J. Clin. Nutr. 2005, 82, 636-643. [CrossRef] [PubMed]

170. Robinson, N.; Grabowski, P.; Rehman, I. Alzheimer's disease pathogenesis: Is there a role for folate? Mech. Ageing Dev. 2018, 174, 86-94. [CrossRef]

171. Smith, A.D.; Refsum, H.; Bottiglieri, T.; Fenech, M.; Hooshmand, B.; McCaddon, A.; Miller, J.W.; Rosenberg, I.H.; Obeid, R Homocysteine and dementia: An international consensus statement. J. Alzheimers Dis. 2018, 62, 561-570. [CrossRef]

172. Kennedy, B.P.; Bottiglieri, T.; Arning, E.; Ziegler, M.G.; Hansen, L.A.; Masliah, E. Elevated s-adenosylhomocysteine in alzheimer brain: Influence on methyltransferases and cognitive function. J. Neural. Transm. 2004, 111, 547-567. [CrossRef] [PubMed]

173. Fuso, A.; Seminara, L.; Cavallaro, R.A.; D'Anselmi, F.; Scarpa, S. S-adenosylmethionine/homocysteine cycle alterations modify DNA methylation status with consequent deregulation of ps1 and bace and beta-amyloid production. Mol. Cell. Neurosci. 2005, 28, 195-204. [CrossRef] [PubMed]

174. O’Brien, R.J.; Wong, P.C. Amyloid precursor protein processing and alzheimer's disease. Annu. Rev. NeuroSci. 2011, 34, 185-204. [CrossRef]

175. Fuso, A.; Nicolia, V.; Cavallaro, R.A.; Ricceri, L.; D’Anselmi, F.; Coluccia, P.; Calamandrei, G.; Scarpa, S. B-vitamin deprivation induces hyperhomocysteinemia and brain s-adenosylhomocysteine, depletes brain s-adenosylmethionine, and enhances ps1 and bace expression and amyloid- $\beta$ deposition in mice. Mol. Cell. Neurosci. 2008, 37, 731-746. [CrossRef]

176. Do Carmo, S.; Hanzel, C.E.; Jacobs, M.L.; Machnes, Z.; Iulita, M.F.; Yang, J.; Yu, L.; Ducatenzeiler, A.; Danik, M.; Breuillaud, L.S.; et al. Rescue of early bace-1 and global DNA demethylation by s-adenosylmethionine reduces amyloid pathology and improves cognition in an alzheimer's model. Sci. Rep. 2016, 6. [CrossRef] [PubMed]

177. Wang, S.C.; Oelze, B.; Schumacher, A. Age-specific epigenetic drift in late-onset alzheimer's disease. PLoS ONE 2008, 3, 0002698. [CrossRef] [PubMed]

178. Iwata, A.; Nagata, K.; Hatsuta, H.; Takuma, H.; Bundo, M.; Iwamoto, K.; Tamaoka, A.; Murayama, S.; Saido, T.; Tsuji, S. Altered cpg methylation in spoRadic. alzheimer's disease is associated with app and mapt dysregulation. Hum. Mol. Genet. 2013, 23, 648-656. [CrossRef]

179. Fuso, A.; Nicolia, V.; Pasqualato, A.; Fiorenza, M.T.; Cavallaro, R.A.; Scarpa, S. Changes in presenilin 1 gene methylation pattern in diet-induced b vitamin deficiency. NeuroBiol. Aging 2011, 32, 187-199. [CrossRef] [PubMed]

180. Fuso, A.; Nicolia, V.; Ricceri, L.; Cavallaro, R.A.; Isopi, E.; Mangia, F.; Fiorenza, M.T.; Scarpa, S. S-adenosylmethionine reduces the progress of the alzheimer-like features induced by b-vitamin deficiency in mice. NeuroBiol. Aging 2012, 33, 4. [CrossRef]

181. Monti, N.; Cavallaro, R.A.; Stoccoro, A.; Nicolia, V.; Scarpa, S.; Kovacs, G.G.; Fiorenza, M.T.; Lucarelli, M.; Aronica, E.; Ferrer, I.; et al. Cpg and non-cpg presenilin1 methylation pattern in course of neurodevelopment and neurodegeneration is associated with gene expression in human and murine brain. Epigenetics 2020, 15, 781-799. [CrossRef]

182. Tian, T.; Bai, D.; Li, W.; Huang, G.-W.; Liu, H. Effects of folic acid on secretases involved in a $\beta$ deposition in app/ps1 mice. Nutrients 2016, 8, 556. [CrossRef] [PubMed]

183. Fuso, A.; Nicolia, V.; Cavallaro, R.A.; Scarpa, S. DNA methylase and demethylase activities are modulated by one-carbon metabolism in alzheimer's disease models. J. Nutr. Biochem. 2011, 22, 242-251. [CrossRef]

184. Li, W.; Liu, H.; Yu, M.; Zhang, X.; Zhang, M.; Wilson, J.X.; Huang, G. Folic acid administration inhibits amyloid $\beta$-peptide accumulation in app/ps1 transgenic mice. J. Nutr. Biochem. 2015, 26, 883-891. [CrossRef] [PubMed]

185. Barrachina, M.; Ferrer, I. DNA methylation of alzheimer disease and tauopathy-related genes in postmortem brain. J. NeuroPathol. Exp. Neurol. 2009, 68, 880-891. [CrossRef]

186. Stoccoro, A.; Tannorella, P.; Migliore, L.; Coppedè, F. Polymorphisms of genes required for methionine synthesis and DNA methylation influence mitochondrial DNA methylation. Epigenomics 2020, 12, 1003-1012. [CrossRef]

187. Blanch, M.; Mosquera, J.L.; Ansoleaga, B.; Ferrer, I.; Barrachina, M. Altered mitochondrial DNA methylation pattern in alzheimer disease-related pathology and in parkinson disease. Am. J. Pathol. 2016, 186, 385-397. [CrossRef]

188. Janssens, V.; Longin, S.; Goris, J. Pp2a holoenzyme assembly: In cauda venenum (the sting is in the tail). Trends BioChem. Sci. 2008, 33, 113-121. [CrossRef] [PubMed] 
189. Sontag, E.; Hladik, C.; Montgomery, L.; Luangpirom, A.; Mudrak, I.; Ogris, E.; White, C.L., 3rd. Downregulation of protein phosphatase 2a carboxyl methylation and methyltransferase may contribute to alzheimer disease pathogenesis. J. NeuroPathol. Exp. Neurol. 2004, 63, 1080-1091. [CrossRef]

190. Zhou, X.W.; Gustafsson, J.A.; Tanila, H.; Bjorkdahl, C.; Liu, R.; Winblad, B.; Pei, J.J. Tau hyperphosphorylation correlates with reduced methylation of protein phosphatase 2a. NeuroBiol. Dis. 2008, 31, 386-394. [CrossRef]

191. Sontag, J.M.; Nunbhakdi-Craig, V.; Montgomery, L.; Arning, E.; Bottiglieri, T.; Sontag, E. Folate deficiency induces in vitro and mouse brain region-specific downregulation of leucine carboxyl methyltransferase- 1 and protein phosphatase $2 a$ b(alpha) subunit expression that correlate with enhanced tau phosphorylation. J. NeuroSci. 2008, 28, 11477-11487. [CrossRef]

192. Zheng, M.; Zou, C.; Li, M.; Huang, G.; Gao, Y.; Liu, H. Folic acid reduces tau phosphorylation by regulating pp2a methylation in streptozotocin-induced diabetic mice. Int. J. Mol. Sci. 2017, 18, 861. [CrossRef] [PubMed]

193. Park, H.J.; Lee, K.W.; Oh, S.; Yan, R.; Zhang, J.; Beach, T.G.; Adler, C.H.; Voronkov, M.; Braithwaite, S.P.; Stock, J.B.; et al. Protein phosphatase $2 \mathrm{a}$ and its methylation modulating enzymes lcmt-1 and pme- 1 are dysregulated in tauopathies of progressive supranuclear palsy and alzheimer disease. J. NeuroPathol. Exp. Neurol. 2018, 77, 139-148. [CrossRef] [PubMed]

194. Nasa, I.; Kettenbach, A.N. Effects of carboxyl-terminal methylation on holoenzyme function of the pp2a subfamily. BioChem. Soc. Trans. 2020, 48, 2015-2027. [CrossRef]

195. Li, W.; Jiang, M.; Xiao, Y.; Zhang, X.; Cui, S.; Huang, G. Folic acid inhibits tau phosphorylation through regulation of pp2a methylation in sh-sy5y cells. J. Nutr. Health Aging 2015, 19, 123-129. [CrossRef] [PubMed]

196. Sontag, E.; Nunbhakdi-Craig, V.; Sontag, J.M.; Diaz-Arrastia, R.; Ogris, E.; Dayal, S.; Lentz, S.R.; Arning, E.; Bottiglieri, T. Protein phosphatase 2a methyltransferase links homocysteine metabolism with tau and amyloid precursor protein regulation. J. NeuroSci. 2007, 27, 2751-2759. [CrossRef] [PubMed]

197. Taleski, G.; Schuhmacher, D.; Su, H.; Sontag, J.-M.; Sontag, E. Disturbances in pp2a methylation and one-carbon metabolism compromise fyn distribution, neuritogenesis, and app regulation. J. Biol. Chem. 2021, 296. [CrossRef] [PubMed]

198. Sontag, J.-M.; Wasek, B.; Taleski, G.; Smith, J.; Arning, E.; Sontag, E.; Bottiglieri, T. Altered protein phosphatase 2a methylation and tau phosphorylation in the young and aged brain of methylenetetrahydrofolate reductase (mthfr) deficient mice. Front. Aging NeuroSci. 2014, 6, 214. [CrossRef] [PubMed]

199. Zhang, C.E.; Tian, Q.; Wei, W.; Peng, J.H.; Liu, G.P.; Zhou, X.W.; Wang, Q.; Wang, D.W.; Wang, J.Z. Homocysteine induces tau phosphorylation by inactivating protein phosphatase 2a in rat hippocampus. NeuroBiol. Aging 2008, 29, 1654-1665. [CrossRef]

200. Ho, P.I.; Collins, S.C.; Dhitavat, S.; Ortiz, D.; Ashline, D.; Rogers, E.; Shea, T.B. Homocysteine potentiates beta-amyloid neurotoxicity: Role of oxidative stress. J. NeuroChem. 2001, 78, 249-253. [CrossRef]

201. McCaddon, A.; Hudson, P.; Hill, D.; Barber, J.; Lloyd, A.; Davies, G.; Regland, B.j. Alzheimer's disease and total plasma aminothiols. Biol. Psychiatry 2003, 53, 254-260. [CrossRef]

202. Zafrilla, P.; Mulero, J.; Xandri, M.J.; Santo, E.; Caravaca, G.; Morillas, M.J. Oxidative stress in alzheimer patients in different stages of the disease. Curr. Med. Chem. 2006, 13, 1075-1083. [CrossRef] [PubMed]

203. Resende, R.; Moreira, P.I.; Proença, T.; Deshpande, A.; Busciglio, J.; Pereira, C.; Oliveira, C.R. Brain oxidative stress in a triple-transgenic mouse model of alzheimer disease. Free Radic. Biol. Med. 2008, 44, 2051-2057. [CrossRef] [PubMed]

204. Cankurtaran, M.; Yesil, Y.; Kuyumcu, M.E.; Oztürk, Z.A.; Yavuz, B.B.; Halil, M.; Ulger, Z.; Cankurtaran, E.S.; Arıogul, S. Altered levels of homocysteine and serum natural antioxidants links oxidative damage to alzheimer's disease. J. Alzheimers Dis. 2013, 33, 1051-1058. [CrossRef]

205. Ghodake, S.R.; Suryakar, A.N.; Kulhalli, P.M.; Shaikh, A.K. The study of homocysteine and its relationship with oxidative stress biomarkers in alzheimer's disease. Int. J. Med. Sci. Clin. Invent. 2016. [CrossRef]

206. Hama, Y.; Hamano, T.; Shirafuji, N.; Hayashi, K.; Ueno, A.; Enomoto, S.; Nagata, M.; Kimura, H.; Matsunaga, A.; Ikawa, M.; et al. Influences of folate supplementation on homocysteine and cognition in patients with folate deficiency and cognitive impairment. Nutrients 2020, 12, 3138. [CrossRef]

207. Román, G.C. Mthfr gene mutations: A potential marker of late-onset alzheimer's disease? J. Alzheimers Dis. 2015, 47, 323-327. [CrossRef]

208. Beyer, K.; Lao, J.I.; Carrato, C.; Rodriguez-Vila, A.; Latorre, P.; Mataró, M.; Llopis, M.A.; Mate, J.L.; Ariza, A. Cystathionine beta synthase as a risk factor for alzheimer disease. Curr. Alzheimer Res. 2004, 1, 127-133. [CrossRef]

209. The role of cystathionine $\beta$-synthase in homocysteine metabolism. Antioxid. Redox Signal. 2005, 7, 813-822. [CrossRef]

210. Paul, B.D. Neuroprotective roles of the reverse transsulfuration pathway in alzheimer's disease. Front. Aging NeuroSci. 2021, 13. [CrossRef]

211. Tjiattas, L.; Ortiz, D.O.; Dhivant, S.; Mitton, K.; Rogers, E.; Shea, T.B. Folate deficiency and homocysteine induce toxicity in cultured dorsal root ganglion neurons via cytosolic calcium accumulation. Aging Cell 2004, 3, 71-76. [CrossRef] [PubMed]

212. Poddar, R.; Paul, S. Homocysteine-nmda receptor-mediated activation of extracellular signal-regulated kinase leads to neuronal cell death. J. NeuroChem. 2009, 110, 1095-1106. [CrossRef]

213. Danysz, W.; Parsons, C.G. Alzheimer's disease, $\beta$-amyloid, glutamate, nmda receptors and memantine-Searching for the connections. Br. J. Pharm. 2012, 167, 324-352. [CrossRef]

214. Övey, İ.S.; Naziroğlu, M. Homocysteine and cytosolic gsh depletion induce apoptosis and oxidative toxicity through cytosolic calcium overload in the hippocampus of aged mice: Involvement of trpm2 and trpv1 channels. Neuroscience 2015, 284, 225-233. [CrossRef] 
215. Kruman, I.I.; Culmsee, C.; Chan, S.L.; Kruman, Y.; Guo, Z.; Penix, L.; Mattson, M.P. Homocysteine elicits a DNA damage response in neurons that promotes apoptosis and hypersensitivity to excitotoxicity. J. Neurosci. 2000, 20, 6920-6926. [CrossRef] [PubMed]

216. Vanzin, C.S.; Manfredini, V.; Marinho, A.E.; Biancini, G.B.; Ribas, G.S.; Deon, M.; Wyse, A.T.; Wajner, M.; Vargas, C.R. Homocysteine contribution to DNA damage in cystathionine $\beta$-synthase-deficient patients. Gene 2014, 539, 270-274. [CrossRef]

217. Andra, A.; Tanigawa, S.; Bito, T.; Ishihara, A.; Watanabe, F.; Yabuta, Y. Effects of vitamin b(12) deficiency on amyloid- $\beta$ toxicity in caenorhabditis elegans. Antioxidants 2021, 10, 962. [CrossRef]

218. Lam, A.B.; Kervin, K.; Tanis, J.E. Vitamin b12 impacts amyloid beta-induced proteotoxicity by regulating the methionine/sadenosylmethionine cycle. Cell Rep. 2021, 36, 109753. [CrossRef]

219. Leiteritz, A.; Dilberger, B.; Wenzel, U.; Fitzenberger, E. Betaine reduces $\beta$-amyloid-induced paralysis through activation of cystathionine- $\beta$-synthase in an alzheimer model of caenorhabditis elegans. Genes Nutr. 2018, 13, 018-0611. [CrossRef]

220. Bermejo, P.; Martín-Aragón, S.; Benedí, J.; Susín, C.; Felici, E.; Gil, P.; Ribera, J.M.; Villar, A.M. Peripheral levels of glutathione and protein oxidation as markers in the development of alzheimer's disease from mild cognitive impairment. Free Radic. Res. 2008, 42, 162-170. [CrossRef] [PubMed]

221. Mandal, P.K.; Saharan, S.; Tripathi, M.; Murari, G. Brain glutathione levels-a novel biomarker for mild cognitive impairment and alzheimer's disease. Biol. Psychiatry 2015, 78, 702-710. [CrossRef]

222. Ansari, M.A.; Scheff, S.W. Oxidative stress in the progression of alzheimer disease in the frontal cortex. J. NeuroPathol. Exp. Neurol. 2010, 69, 155-167. [CrossRef] [PubMed]

223. Saharan, S.; Mandal, P.K. The emerging role of glutathione in alzheimer's disease. J. Alzheimers Dis. 2014, 40, 519-529. [CrossRef] [PubMed]

224. Poewe, W.; Seppi, K.; Tanner, C.M.; Halliday, G.M.; Brundin, P.; Volkmann, J.; Schrag, A.-E.; Lang, A.E. Parkinson disease. Nat. Rev. Dis. Primers 2017, 3, 17013. [CrossRef]

225. Day, J.O.; Mullin, S. The genetics of parkinson's disease and implications for clinical practice. Genes 2021, 12, 1006. [CrossRef] [PubMed]

226. Murray, L.K.; Jadavji, N.M. The role of one-carbon metabolism and homocysteine in parkinson's disease onset, pathology and mechanisms. Nutr. Res. Rev. 2019, 32, 218-230. [CrossRef] [PubMed]

227. Fan, X.; Zhang, L.; Li, H.; Chen, G.; Qi, G.; Ma, X.; Jin, Y. Role of homocysteine in the development and progression of parkinson's disease. Ann. Clin. Transl. Neurol. 2020, 7, 2332-2338. [CrossRef] [PubMed]

228. Paul, R.; Borah, A. L-dopa-induced hyperhomocysteinemia in parkinson's disease: Elephant in the room. Biochim. Biophys. Acta (BBA)-Gen. Subj. 2016, 1860, 1989-1997. [CrossRef] [PubMed]

229. van der Steen, W.; den Heijer, T.; Groen, J. Vitamin b6 deficiency caused by the use of levodopa. Ned. Tijdschr. Geneeskd. 2018, $23,162$.

230. Rojo-Sebastián, A.; González-Robles, C.; García de Yébenes, J. Vitamin b6 deficiency in patients with parkinson disease treated with levodopa/carbidopa. Clin. Neuropharmacol 2020, 43, 151-157. [CrossRef]

231. Miller, J.W.; Selhub, J.; Nadeau, M.R.; Thomas, C.A.; Feldman, R.G.; Wolf, P.A. Effect of l-dopa on plasma homocysteine in pd patients: Relationship to b-vitamin status. Neurology 2003, 60, 1125-1129. [CrossRef]

232. dos Santos, E.F.; Busanello, E.N.; Miglioranza, A.; Zanatta, A.; Barchak, A.G.; Vargas, C.R.; Saute, J.; Rosa, C.; Carrion, M.J.; Camargo, D.; et al. Evidence that folic acid deficiency is a major determinant of hyperhomocysteinemia in parkinson's disease. Metab. Brain Dis. 2009, 24, 257-269. [CrossRef]

233. Murakami, K.; Miyake, Y.; Sasaki, S.; Tanaka, K.; Fukushima, W.; Kiyohara, C.; Tsuboi, Y.; Yamada, T.; Oeda, T.; Miki, T.; et al. Dietary intake of folate, vitamin b6, vitamin b12 and riboflavin and risk of parkinson's disease: A case-control study in japan. Br. J. Nutr. 2010, 104, 757-764. [CrossRef] [PubMed]

234. Shen, L. Associations between b vitamins and parkinson's disease. Nutrients 2015, 7, 7197-7208. [CrossRef] [PubMed]

235. Christine, C.W.; Auinger, P.; Joslin, A.; Yelpaala, Y.; Green, R. Vitamin b12 and homocysteine levels predict different outcomes in early parkinson's disease. Mov. Disord. 2018, 33, 762-770. [CrossRef]

236. Luthra, N.S.; Marcus, A.H.; Hills, N.K.; Christine, C.W. Vitamin b12 measurements across neurodegenerative disorders. J. Clin. Mov. Disord. 2020, 7, 3. [CrossRef] [PubMed]

237. Ibrahimagic, O.C.; Smajlovic, D.; Dostovic, Z.; Pasic, Z.; Kunic, S.; Iljazovic, A.; Hajdarevic, D.S. Hyperhomocysteinemia and its treatment in patients with parkinson's disease. Mater. Sociomed 2016, 28, 303-306. [CrossRef]

238. Chen, H.; Zhang, S.M.; Schwarzschild, M.A.; Hernán, M.A.; Logroscino, G.; Willett, W.C.; Ascherio, A. Folate intake and risk of parkinson's disease. Am. J. Epidemiol. 2004, 160, 368-375. [CrossRef] [PubMed]

239. de Lau, L.M.; Koudstaal, P.J.; Witteman, J.C.; Hofman, A.; Breteler, M.M. Dietary folate, vitamin b12, and vitamin b6 and the risk of parkinson disease. Neurology 2006, 67, 315-318. [CrossRef]

240. Diao, H.-M.; Song, Z.-F.; Xu, H.-D. Association between mthfr genetic polymorphism and parkinson's disease susceptibility: A meta-analysis. Open Med. 2019, 14, 613-624. [CrossRef]

241. Liu, L.; Zhang, L.; Guo, L.; Yu, Q.; Li, H.; Teng, J.; Xie, A. Mthfr c677t and a1298c polymorphisms may contribute to the risk of parkinson's disease: A meta-analysis of 19 studies. NeuroSci. Lett. 2018, 662, 339-345. [CrossRef]

242. Fong, C.S.; Shyu, H.Y.; Shieh, J.C.; Fu, Y.P.; Chin, T.Y.; Wang, H.W.; Cheng, C.W. Association of mthfr, mtr, and mtrr polymorphisms with parkinson's disease among ethnic chinese in taiwan. Clin. Chim Acta 2011, 412, 332-338. [CrossRef] 
243. Miranda-Morales, E.; Meier, K.; Sandoval-Carrillo, A.; Salas-Pacheco, J.; Vázquez-Cárdenas, P.; Arias-Carrión, O. Implications of DNA methylation in parkinson's disease. Front. Mol. NeuroSci. 2017, 10. [CrossRef] [PubMed]

244. Henderson, A.R.; Wang, Q.; Meechoovet, B.; Siniard, A.L.; Naymik, M.; De Both, M.; Huentelman, M.J.; Caselli, R.J.; DriverDunckley, E.; Dunckley, T. DNA methylation and expression profiles of whole blood in parkinson's disease. Front. Genet. $2021,12$. [CrossRef]

245. Jowaed, A.; Schmitt, I.; Kaut, O.; Wüllner, U. Methylation regulates alpha-synuclein expression and is decreased in parkinson's disease patients' brains. J. NeuroSci. 2010, 30, 6355-6359. [CrossRef] [PubMed]

246. Matsumoto, L.; Takuma, H.; Tamaoka, A.; Kurisaki, H.; Date, H.; Tsuji, S.; Iwata, A. Cpg demethylation enhances alpha-synuclein expression and affects the pathogenesis of parkinson's disease. PLoS ONE 2010, 5, 0015522. [CrossRef] [PubMed]

247. Ai, S.X.; Xu, Q.; Hu, Y.C.; Song, C.Y.; Guo, J.F.; Shen, L.; Wang, C.R.; Yu, R.L.; Yan, X.X.; Tang, B.S. Hypomethylation of snca in blood of patients with spoRadic. parkinson's disease. J. Neurol. Sci. 2014, 337, 123-128. [CrossRef]

248. Guhathakurta, S.; Evangelista, B.A.; Ghosh, S.; Basu, S.; Kim, Y.-S. Hypomethylation of intron1 of $\alpha$-synuclein gene does not correlate with parkinson's disease. Mol. Brain 2017, 10, 6. [CrossRef] [PubMed]

249. Gu, J.; Barrera, J.; Yun, Y.; Murphy, S.K.; Beach, T.G.; Woltjer, R.L.; Serrano, G.E.; Kantor, B.; Chiba-Falek, O. Cell-type specific changes in DNA methylation of snca intron 1 in synucleinopathy brains. Front. Neurosci. 2021, 15. [CrossRef]

250. Obeid, R.; Schadt, A.; Dillmann, U.; Kostopoulos, P.; Fassbender, K.; Herrmann, W. Methylation status and neurodegenerative markers in parkinson disease. Clin. Chem. 2009, 55, 1852-1860. [CrossRef] [PubMed]

251. Desplats, P.; Spencer, B.; Coffee, E.; Patel, P.; Michael, S.; Patrick, C.; Adame, A.; Rockenstein, E.; Masliah, E. Alpha-synuclein sequesters dnmt1 from the nucleus: A novel mechanism for epigenetic alterations in lewy body diseases. J. Biol. Chem. 2011, 286, 9031-9037. [CrossRef]

252. Lüth, T.; Wasner, K.; Klein, C.; Schaake, S.; Tse, R.; Pereira, S.L.; Laß, J.; Sinkkonen, L.; Grünewald, A.; Trinh, J. Nanopore single-molecule sequencing for mitochondrial DNA methylation analysis: Investigating parkin-associated parkinsonism as a proof of concept. Front. Aging NeuroSci. 2021, 13. [CrossRef]

253. Malpartida, A.B.; Williamson, M.; Narendra, D.P.; Wade-Martins, R.; Ryan, B.J. Mitochondrial dysfunction and mitophagy in parkinson's disease: From mechanism to therapy. Trends Biochem. Sci. 2021, 46, 329-343. [CrossRef]

254. Guo, J.D.; Zhao, X.; Li, Y.; Li, G.R.; Liu, X.L. Damage to dopaminergic neurons by oxidative stress in parkinson's disease (review). Int. J. Mol. Med. 2018, 41, 1817-1825. [CrossRef]

255. Bjørklund, G.; Peana, M.; Maes, M.; Dadar, M.; Severin, B. The glutathione system in parkinson's disease and its progression. Neurosci. Biobehav. Rev. 2021, 120, 470-478. [CrossRef] [PubMed]

256. Chinta, S.J.; Kumar, M.J.; Hsu, M.; Rajagopalan, S.; Kaur, D.; Rane, A.; Nicholls, D.G.; Choi, J.; Andersen, J.K. Inducible alterations of glutathione levels in adult dopaminergic midbrain neurons result in nigrostriatal degeneration. J. NeuroSci. 2007, 27, 13997-14006. [CrossRef] [PubMed]

257. Srivastav, S.; Singh, S.K.; Yadav, A.K.; Srikrishna, S. Folic acid supplementation ameliorates oxidative stress, metabolic functions and developmental anomalies in a novel fly model of parkinson's disease. Neurochem. Res. 2015, 40, 1350-1359. [CrossRef]

258. Meiser, J.; Delcambre, S.; Wegner, A.; Jäger, C.; Ghelfi, J.; d'Herouel, A.F.; Dong, X.; Weindl, D.; Stautner, C.; Nonnenmacher, Y.; et al. Loss of dj-1 impairs antioxidant response by altered glutamine and serine metabolism. Neurobiol. Dis. 2016, 89, 112-125. [CrossRef] [PubMed] 